\title{
Biomethanation of Syngas by Enriched Mixed Anaerobic Consortia in Trickle Bed Reactors
}

\author{
Asimakopoulos, Konstantinos; Gavala, Hariklia N.; Skiadas, loannis V.
}

Published in:

Waste and Biomass Valorization

Link to article, DOI:

10.1007/s12649-019-00649-2

Publication date:

2020

Document Version

Peer reviewed version

Link back to DTU Orbit

Citation $(A P A)$ :

Asimakopoulos, K., Gavala, H. N., \& Skiadas, I. V. (2020). Biomethanation of Syngas by Enriched Mixed Anaerobic Consortia in Trickle Bed Reactors. Waste and Biomass Valorization, 11, 495-512. https://doi.org/10.1007/s12649-019-00649-2

\section{General rights}

Copyright and moral rights for the publications made accessible in the public portal are retained by the authors and/or other copyright owners and it is a condition of accessing publications that users recognise and abide by the legal requirements associated with these rights.

- Users may download and print one copy of any publication from the public portal for the purpose of private study or research.

- You may not further distribute the material or use it for any profit-making activity or commercial gain

- You may freely distribute the URL identifying the publication in the public portal 
1 Title: Biomethanation of Syngas by Enriched Mixed Anaerobic Consortia in 2 Trickle Bed Reactors

4 Konstantinos Asimakopoulos, Hariklia N. Gavala, loannis V. Skiadas*

5 Department of Chemical and Biochemical Engineering, Technical University of Denmark, Søltofts

6 Plads 229, 2800 Lyngby, Denmark

7

$8 \quad$ *Corresponding author e-mail address: ivsk@kt.dtu.dk / phone number: +4545252729

9

\section{Abstract}

22 Two identical Trickle-Bed Reactor setups were designed and operated under mesophilic conditions and

\section{Authors ORCID numbers}

Konstantinos Asimakopoulos: 0000-0003-2786-8603

Hariklia N. Gavala: 0000-0002-3924-5334

loannis V. Skiadas: 0000-0001-6183-4592

Keywords: Syngas, Biomethanation, Mixed Cultures, Trickle Bed Reactors, Carbon Monoxide, Biofuels

\section{Acknowledgements}

This study was financially supported by Innovation Foundation - DK and the Chemical and Biochemical Engineering department at the Technical University of Denmark in the frame of SYNFERON project.

\section{Conflict of interests}

The authors declare that there is no conflict of interest atmospheric pressure, without $\mathrm{pH}$ control, for the biomethanation of syngas consisted of $45 \% \mathrm{H}_{2}, 25 \% \mathrm{CO}_{2}$, $20 \% \mathrm{CO}$ and $10 \% \mathrm{CH}_{4}$. The reactors were inoculated with mixed methanogenic microbial consortia formerly 
adapted to the gaseous mixture. During the start-up of the reactors acetic acid accumulation in the liquid broth resulted in a pH decrease to levels unfavorable for methanogenic activity. This was corrected by introducing a strong phosphate buffer in the medium $\left(\mathrm{K}_{2} \mathrm{HPO}_{4} / \mathrm{KH}_{2} \mathrm{PO}_{4}: 87 \mathrm{mM} / 13 \mathrm{mM}\right)$. Channeling phenomena observed across the trickle bed were eliminated by setting a high liquid recirculation rate $\left(1600 \mathrm{I} / \mathrm{l}_{\mathrm{bed}} / \mathrm{d}\right)$. The reactors were operated for 294 days presenting minor deviations between them at the 24 extracted steady states and high cells retention even at a hydraulic retention time of 3.7 days. At a gas residence time of 2.31 hours and a hydraulic retention time of 5.5 days the achieved $\mathrm{CH}_{4}$ productivity was 2 $\mathrm{mmol} / \mathrm{l}_{\text {bed }} / \mathrm{h}$ with $93 \% \mathrm{H}_{2}$ and $90 \% \mathrm{CO}$ conversion efficiency and a $78 \%$ electron yield to $\mathrm{CH}_{4}$. The conducted study verified that an enriched methanogenic microbial consortium can effectively convert syngas to $\mathrm{CH}_{4}$ in a trickle bed reactor under appropriate operational conditions.

\section{Statement of Novelty}

Syngas can be produced from biomass gasification and also it is a byproduct of several industrial processes. It is carrier of a high amount of energy and carbon that cannot be stored (due to high content of $\mathrm{H}_{2}$ and $\mathrm{CO}$ ) unless it is processed. The presented work introduces a potential solution by fixing the carbon and energy content of syngas into $\mathrm{CH}_{4}$, a compound that can be easily stored in the natural gas grid. The proposed biological process was, to our knowledge, performed for the first time by enriched mixed microbial consortia in a trickle bed reactor and sheds light on the effects of operational parameters, such as the composition of the mineral medium, the liquid recirculation rate, the hydraulic retention time and the gas retention time.

\section{Introduction}

The total population of the world is rising very fast, projected by the United Nations to surpass 9.5 billion by 2040 [1]. In the same time frame, the global energy consumption is expected to increase by $28 \%$ [2], indicating the urgency of a shift from the dependency on fossil fuels, which are limited [3], towards renewable sources of energy. Establishing a biobased economy is also essential due to the tangible effects 
1 of climate change on our planet [4]. First-generation biofuels ignited a lot of bickering and controversy targeted over the "food vs fuel" deliberation and, therefore, opened the path leading to second-generation (2G) biofuels production which is more sustainable and attractive to the policymakers [5]. A feedstock for $2 \mathrm{G}$ biofuels that has recently drawn a lot of attention [6-9] is synthesis gas or syngas, a gas mixture consisting mainly of $\mathrm{CO}, \mathrm{H}_{2}$ and $\mathrm{CO}_{2}$.

Syngas is a product of the gasification of biomass [10] and a byproduct of many industrial processes such as steel milling, petroleum refining and waste incineration $[11,12]$. Its abundancy and its content in $\mathrm{CO}$ and $\mathrm{H}_{2}$ render it, though, an important source of energy to be exploited. Yet, the vast storage capacity of the natural gas grid cannot be used for syngas due to its content in $\mathrm{CO}, \mathrm{H}_{2}$ and $\mathrm{CO}_{2}$ and, as a result, it has to be processed either chemically or biologically to form storable products. Furthermore, biological syngas conversion presents many advantages compared to the chemical catalysis alternative such as mild temperature and pressure, no demand for fixed $\mathrm{H}_{2} / \mathrm{CO}$ in syngas, high product specificity and high tolerance to poisoning from impurities $[13,14]$. However, production of $2 \mathrm{G}$ biofuels through syngas fermentation has not reached a commercial stage yet, mainly because of the low mass transfer rate of CO and $\mathrm{H}_{2}$ to the water-based microbial cultures and the relatively low growth rate of the anaerobic microorganisms $[15,16]$. Recently, the progress of Lanzatech in its efforts for commercial on site syngas fermentation of $\mathrm{CO}$ rich gases from steel mills to ethanol shows that the first fully operational commercial scale plant is approaching [12].

The most studied products of syngas bioconversion are ethanol and acetic acid with a trend towards the production of heterologous products springing up along with innovative techniques in metabolic engineering [17]. Apart from liquid biofuels and commodity chemicals, biomethane is gathering more and more attention over the last few years due to its high energy content that allows it to be used as a vehicle fuel and its convenience to be introduced in the natural gas grid when it covers the specifications $[15,18]$ thus resulting in also exploiting the large storage capacity of the gas grid. In addition, syngas 
biomethanation has the advantage to be able to be performed by mixed microbial consortia without the need of sterilization expenses. These consortia are broadly available in waste and wastewater treatment anaerobic environments, hence they come at no cost [19] and they present high robustness since they grow under harsh environmental conditions [20].

5 The microbial groups that are principally involved in syngas biomethanation are carboxydotrophic hydrogenogens, methanogens and acetogens, hydrogenotrophic methanogens, homoacetogens and acetoclastic methanogens [21]. The biological reactions catalyzed by the aforementioned microbes are presented in Table 1. No matter which sequence of these reactions is followed for the production of $\mathrm{CH}_{4}$, the maximum overall stoichiometric molar conversion of $\mathrm{H}_{2}$ plus $\mathrm{CO}$ to $\mathrm{CH}_{4}$ is $25 \%$, independent of the ratio between $\mathrm{H}_{2}$ and $\mathrm{CO}$ and the fraction of $\mathrm{CO}_{2}$ in syngas. $\mathrm{H}_{2}$ is an electron donor and therefore acts as an energy source, $\mathrm{CO}$ can act both as an energy source and a carbon source while $\mathrm{CO}_{2}$ is a fully oxidized molecule and can only act as a carbon source. This allows a diverse consortium of microbes to grow syntrophically on this gaseous substrate depending on their preferred energy and carbon source and the occurring metabolites.

Table 1. Biological reactions corresponding to the different microbial groups involved in syngas biomethanation. The standard change of Gibbs free energy was adapted by Grimalt et al. [15]

\begin{tabular}{|c|c|c|}
\hline Microbial Group & Biocatalytic reaction & $\mathbf{\Delta G}^{\mathbf{0}}(\mathbf{k J} / \mathbf{m o l})$ \\
\hline Carboxydotrophic hydrogenogens & $\mathrm{CO}+\mathrm{H}_{2} \mathrm{O} \rightarrow \mathrm{CO}_{2}+\mathrm{H}_{2}$ & -20 \\
\hline Carboxydotrophic methanogens & $4 \mathrm{CO}+2 \mathrm{H}_{2} \mathrm{O} \rightarrow 3 \mathrm{CO}_{2}+\mathrm{CH}_{4}$ & -210.9 \\
\hline Carboxydotrophic acetogens & $4 \mathrm{CO}+2 \mathrm{H}_{2} \mathrm{O} \rightarrow \mathrm{CH}_{3} \mathrm{COOH}_{2} \mathrm{CO}_{2}$ & -165.4 \\
\hline Hydrogenotrophic methanogens & $\mathrm{CO}_{2}+4 \mathrm{H}_{2} \rightarrow \mathrm{CH}_{4}+2 \mathrm{H}_{2} \mathrm{O}$ & -135.6 \\
\hline Homoacetogens & $2 \mathrm{CO}_{2}+4 \mathrm{H}_{2} \rightarrow \mathrm{CH}_{3} \mathrm{COOH}+2 \mathrm{H}_{2} \mathrm{O}$ & -104.6 \\
\hline Acetoclastic methanogens & $\mathrm{CH}_{3} \mathrm{COOH} \rightarrow \mathrm{CH}_{4}+\mathrm{CO}_{2}$ & -31 \\
\hline
\end{tabular}

18

Besides the selection of the type of the biocatalysts, a crucial parameter that should be thoroughly considered in syngas fermentation processes is the bioreactor configuration employed since it is associated with the circumvention of the poor gas-to-liquid mass transfer [22]. Undoubtedly, the most studied and used bioreactor in gas fermentations is the stirred-tank due to its simplicity and the limited optimization of 
1 parameters needed (impeller configuration, agitation speed, gas flow rate and gas injection module) [23]. In order to increase the mass transfer rate in this type of reactors, the goal is to decrease the size and the retention of the gas bubbles and as a result provide higher gas-liquid interfacial area. Compared to stirred tank reactors, trickle bed reactors have been reported to provide improved gas-to-liquid mass transfer rates [24] due to their high surface per volume ratio available from the packing material, where biofilm grows. This advantage comes at a lower cost because of the absence of mechanical mixing. Another major advantage of trickle bed reactors is cell retention because of the inherent ability of a big diversity of microbes to form biofilms [25]. Whereas, in many cases biofilm formation is connected with fouling phenomena [26], this is not the case in trickle bed reactors for syngas fermentation where the organic loading rate is low and does not allow for high microbial growth. The basic drawback is channeling [27], that is the flow of the liquid through limited paths across the packed bed resulting in a non-homogenous biofilm growth in the reactor and lower $\mathrm{CH}_{4}$ productivity rates. The operational parameters that are amenable to optimization are the liquid recirculation rate, the gas inflow rate and the hydraulic retention time. In addition to these, principal design parameters are the diameter/height ratio of the column, the type of the packing material and its geometry, the module of the introduction of the liquid and the gas in the column as well as the orientation of the flow of the gas and the liquid stream (co-current or countercurrent) [28].

Trickle bed reactors have been studied for syngas fermentation and biogas upgrade due to the demand of a high gas to liquid mass transfer for these processes. Kimmel et al. [29] and Klasson et al. [30] were the first ones to report the potential of syngas biomethanation with trickle bed reactors and the improved methane productivities achieved compared to bubble columns. In their research the biological conversion of syngas was performed by a synergistic microbial triculture of Rhodospirillum rubrum, Methanosarcina barkeri, and Methanobacterium formicicum. Rachbauer et al. [31] and Burkhardt et al. [32, 33] assessed the use of a mesophilic hydrogenotrophic mixed microbial culture in a trickle bed reactor for the upgrade of biogas produced from anaerobic digestion with the supply of $\mathrm{H}_{2}$ and showed that the setup could produce a $\mathrm{CH}_{4}$ 
rich gas following all the prerequisites to be injected in a natural gas grid. Improved methane productivity rates were reported by Strübing et al. $[34,35]$ when $\mathrm{H}_{2} / \mathrm{CO}_{2}$ methanation was performed under thermophilic conditions with mixed microbial consortia. Alternative reactor configurations reported in literature for syngas biomethanation are reverse membrane bioreactors $[36,37]$ and multi - orifice baffled bioreactors [38].

The purpose of this study was to assess the methanogenic potential of syngas bioconversion by enriched mixed microbial consortia in a trickle bed reactor and designate those operational parameters that affect predominantly the conversion efficiency of the syngas components to $\mathrm{CH}_{4}$. Furthermore, we examined how the range of liquid byproducts is affected by specific changes in operational parameters. To our knowledge this is the first study of syngas biomethanation in trickle bed reactors by enriched mixed microbial consortia.

\section{Materials and Methods}

\subsection{Inoculum}

Anaerobic sludge was collected from the Lundtofte Wastewater Treatment plant (Lundtofte, Denmark) and from a lab-scale manure treating anaerobic digester (Chemical and Biochemical Engineering Department, Technical University of Denmark). The two anaerobic sludges were mixed in equal volumes $(50 / 50 \mathrm{v} / \mathrm{v})$ and then a batch enrichment process, which is meticulously described by Grimalt et al. [39], was applied. Briefly, the enrichments took place in anaerobic serum vials at $37{ }^{\circ} \mathrm{C}$ and $\mathrm{pH} 7$ with $1.3 \mathrm{~atm}, 0.4 \mathrm{~atm}$ and $0.3 \mathrm{~atm}$ partial pressure of $\mathrm{H}_{2}, \mathrm{CO}$ and $\mathrm{CO}_{2}$, respectively, in the headspace.

The enriched cultures were stored in $15 \% \mathrm{w} / \mathrm{w}$ glycerol freeze stock cultures. Before their inoculation to the reactors, they were reactivated by incubation at $37^{\circ} \mathrm{C}$ with 2 atm of synthetic gaseous substrate $\left(45 \% \mathrm{H}_{2}\right.$, $25 \% \mathrm{CO}_{2}, 20 \% \mathrm{CO}$ and $\left.10 \% \mathrm{CH}_{4}\right)$ in the headspace.

\subsection{Growth medium composition}

The medium used for the enrichment process and the reactivation of the microbes as well as for the initiation of the bioreactor experiments is a modified basic anaerobic medium (BA) consisting of a buffering 
1 system, salts, vitamins, trace elements, a chelating and a reducing agent. The composition of the growth

2 media is outlined in Table 2. Solution A is an aqueous solution of $\mathrm{NH}_{4} \mathrm{Cl}(100 \mathrm{~g} / \mathrm{L}), \mathrm{NaCl}(10 \mathrm{~g} / \mathrm{L}), \mathrm{MgCl}_{2}$

3 hexahydrate $(10 \mathrm{~g} / \mathrm{L})$ and $\mathrm{CaCl}_{2}$ dihydrate $(5 \mathrm{~g} / \mathrm{L})$. Solution $\mathrm{B}$ is an aqueous solution of anhydrous $\mathrm{K}_{2} \mathrm{HPO}_{4}$

$4 \quad(151.53 \mathrm{~g} / \mathrm{L})$. Solution $\mathrm{D}$ is an aqueous trace metals solution containing $\mathrm{FeCl}_{2} \cdot 4 \mathrm{H}_{2} \mathrm{O} 2000 \mathrm{mg} / \mathrm{l}, \mathrm{H}_{3} \mathrm{BO}_{3} 50$

$5 \mathrm{mg} / \mathrm{l}, \mathrm{ZnCl}_{2} 50 \mathrm{mg} / \mathrm{l}, \mathrm{CuCl}_{2} 30 \mathrm{mg} / \mathrm{l}, \mathrm{MnCl}_{2} \cdot 4 \mathrm{H}_{2} \mathrm{O} 50 \mathrm{mg} / \mathrm{l},\left(\mathrm{NH}_{4}\right)_{6} \mathrm{Mo}_{7} \mathrm{O}_{24} \cdot 4 \mathrm{H}_{2} \mathrm{O} 50 \mathrm{mg} / \mathrm{l}, \mathrm{AlCl}_{3}, 50 \mathrm{mg} / \mathrm{l}$,

$6 \mathrm{CoCl}_{2} \cdot 6 \mathrm{H}_{2} \mathrm{O}, 50 \mathrm{mg} / \mathrm{l}, \mathrm{NiCl}_{2}, 50 \mathrm{mg} / \mathrm{l}, \mathrm{Na}_{2} \mathrm{SeO}_{3} \cdot 5 \mathrm{H}_{2} \mathrm{O} 100 \mathrm{mg} / \mathrm{l}, \mathrm{Na}_{2} \mathrm{WO}_{4} \cdot 2 \mathrm{H}_{2} \mathrm{O} 60 \mathrm{mg} / \mathrm{l}$ and chelating agent

7 (NTA $1 \mathrm{~g} / \mathrm{l})$. The aqueous Vitamin solution contains vitamins B7, B6, B2, B1, B12, folic acid, nicotinic acid, P-

8 aminobenzoic acid, lipoic, thiotic acid and DL-Pantothenic acid as described by Wolin et al. [40]. $\mathrm{Na}_{2} \mathrm{~S}$ was

9 injected in the medium at anaerobic conditions after flushing with an inert gas $\left(\mathrm{N}_{2}\right)$ and sealing the vial with

10 a rubber stopper.

11 Nevertheless, during the experimental procedures required changes to the medium were applied in order

12 to face observed disturbances from the desired conditions. These changes are described in the Results and

13 Discussion section along with their necessity and their effect on the experimental results.

Table 2. Volume of the solutions added to $1 \mathrm{~L}$ of total medium volume

\begin{tabular}{|c|c|}
\hline Solution & Volume of solution per liter of medium \\
\hline Solution A & $10 \mathrm{ml}$ \\
\hline Solution B & $2 \mathrm{ml}$ \\
\hline Solution D & $1 \mathrm{ml}$ \\
\hline $\mathrm{NaHCO}_{3}(619 \mathrm{mM})$ & $50 \mathrm{ml}$ \\
\hline $\operatorname{Vitamin~Solution~}$ & $10 \mathrm{ml}$ \\
\hline $\mathrm{Na}_{2} \mathrm{~S}(100 \mathrm{mM})$ & $10 \mathrm{ml}$ \\
\hline $\mathrm{H}_{2} \mathrm{O}$ & $917 \mathrm{ml}$ \\
\hline
\end{tabular}




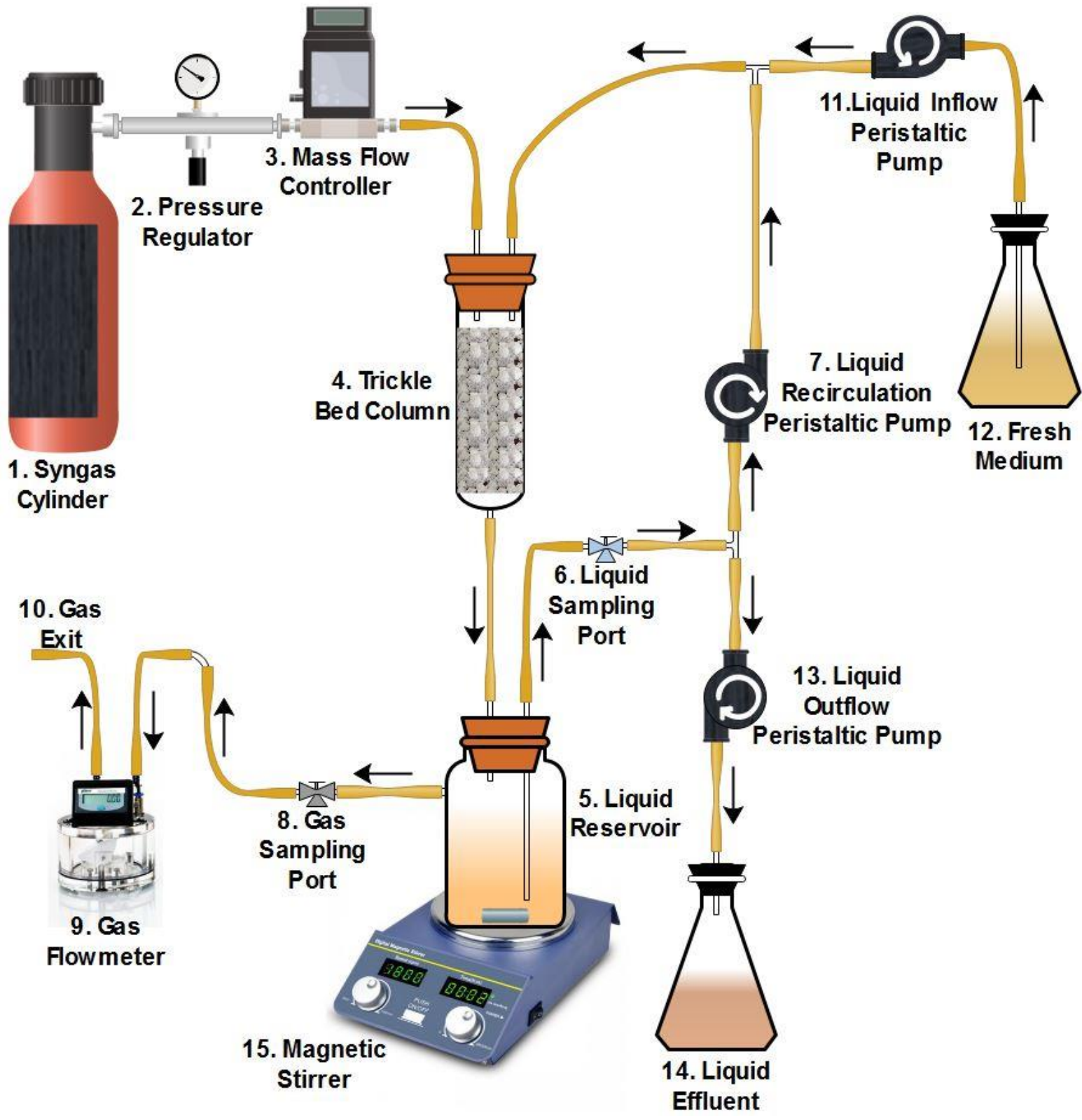

Figure 1. Bioreactor Process Flow Diagram. The basic parts of the lab scale bioreactor setup are 1: Syngas cylinder, 2: Pressure regulator, 3: Mass Flow Controller, 4: Trickle Bed Column, 5: Liquid reservoir, 6: Liquid Sampling port, 7,11,13: Peristaltic pumps, 8: Gas sampling port, 9: Gas flowmeter, 10: Gas exit, 12: Fresh Medium, 14: Liquid Effluent and 15: Magnetic Stirrer The experimental configuration of the trickle bed bioreactor is presented in Fig.1. Artificial syngas with a composition of $45 \% \mathrm{H}_{2}, 25 \% \mathrm{CO}_{2}, 20 \% \mathrm{CO}$ and $10 \% \mathrm{CH}_{4}$ was supplied from a $50 \mathrm{~L}$ gas cylinder $(1, \mathrm{AGA}$ Industrielle gasser) and was flowing through a pressure regulator (2, AGA Industrielle gasser) and a mass flow controller (3, Insatech, Denmark) into the anaerobically sealed trickle bed column (4), which was filled 
with polypropylene/polyethylene packing material (BioFLO 9 - Smoky Mountain Biomedia, USA) with a

2 surface area of $800 \mathrm{~m}^{2} / \mathrm{m}^{3}$ and a density of $1 \mathrm{~g} / \mathrm{cm}^{3}$. The occurring gas mixture after flowing through the trickle bed column was entering the headspace of a liquid reservoir (5) also anaerobically sealed and then it was flowing through a gas sampling port (8) and a gas flowmeter (9, Ritter) before it exited the setup (10). Liquid was continuously recirculated with a peristaltic pump (7, Cole Parmer) from the liquid reservoir to the top of the trickle bed column flowing through a liquid sampling port (6). Continuous liquid inflow and outflow was achieved with an anaerobically sealed bottle containing fresh medium (12) and a collector of the effluent $(14)$ along with two peristaltic pumps $(11,13)$ operated always at the same flow rate. The experimental work was split in two Phases. During Phase 1, the feeding of fresh liquid medium and the removal of equal volume of medium from the liquid reservoir was done manually (that is parts $11,12,13$ and 14 were not installed). In Phase 1 equipment $1-10$ and 15 was installed. Equipment 11-14 was installed after the end of Phase 1 and before the start of Phase 2. In Phase 2 the feeding and the liquid outflow was performed continuously with a peristaltic pump (Cole Parmer). During Phase 2, parts 11, 12, 13 and 14 were installed and the recirculation pump (7) was replaced with a peristaltic pump (Watson Marlow) that could achieve higher flow rates. In short, in terms of the configuration of the reactor the principal distinction between Phase 1 and Phase 2 was the manner in which fresh medium was added in the reactor and liquid effluent was removed. In Phase 1 fresh medium was added manually on a daily basis while in Phase 2 it was added continuously with a peristaltic pump.

The trickle bed column and the liquid reservoir vessel were made of borosilicate glass and had a double wall which allowed temperature regulation via water recirculation from a water bath (Julabo).The liquid reservoir was positioned on top of a magnetic stirrer (15, IKA) set at $150 \mathrm{rpm}$ so as to avoid accumulation of solids (cells or inorganic precipitates) in the liquid reservoir. The temperature was controlled at $37^{\circ} \mathrm{C}$, the pressure was atmospheric and. The volume of the bed was $180 \mathrm{ml}$ (height to diameter ratio was 4.18) and the liquid volume in the reservoir was $180 \mathrm{ml}$ during Phase 1 and $220 \mathrm{ml}$ during Phase 2. Due to the size of the experimental setup a $\mathrm{pH}$ probe could not be fitted and thus the $\mathrm{pH}$ was not controlled. Two identical 
setups were used in order to check the reproducibility of the process. The reactors were covered with black tape so as to ensure that no photosynthetic growth will arise. Finally, in order to verify that the conversion of the syngas was taking place only in the column and not in the reservoir, gas samples were occasionally taken with the addition of a gas sampling port between the bed and the reservoir. The contribution of the reservoir on the conversion of the substrate was negligible.

10 steady states were obtained during Phase 1 and 14 steady states were obtained during Phase 2 . A steady state was considered when in two consecutive days the deviations in the conversion efficiencies of the syngas components and the methane production rate were less than $5 \%$. The obtained 24 steady states are presented in Tables 3 and 4.

\subsection{Analytical Methods}

Gas samples were analyzed for the determination of the molar composition of $\mathrm{CO}, \mathrm{H}_{2}, \mathrm{CO}_{2}$ and $\mathrm{CH}_{4}$ with an SRI $8610 \mathrm{C}$ gas chromatograph. The chromatograph was equipped with a Molsieve $13 \mathrm{X}$ column and a silica gel column with the orientation of the flow of the gaseous phase towards any of the two columns being regulated by a rotating valve. $50 \mu$ l gas samples (model 1750 gas-tight syringe by Hamilton) were injected in the chromatograph and the column temperature was held at $65^{\circ} \mathrm{C}$ for $3 \mathrm{~min}$. Then a temperature ramp of $10{ }^{\circ} \mathrm{C} / \mathrm{min}$ was initiated until the temperature of $95^{\circ} \mathrm{C}$ when the rotating valve was changing the direction of the flow towards the silica gel column with a $24{ }^{\circ} \mathrm{C} / \mathrm{min}$ ramp. $\mathrm{CO}, \mathrm{H}_{2}$ and $\mathrm{CH}_{4}$ were separated by the Molsieve $13 \mathrm{X}$ column before the rotation of the valve while $\mathrm{CO}_{2}$ was separated by the silica gel column after the rotation of the valve. The composition of liquid samples containing volatile fatty acids (VFAs) (acetic acid, propionic acid, butyric acid, iso-butyric acid, valeric acid and caproic acid) and alcohols (ethanol and 1-butanol) were determined with High Performance Liquid Chromatograph (Shimadzu, USA) equipped with a refractive index detector and an Aminex HPX-87H column (Bio-Rad). The temperature of the column was stable at $63{ }^{\circ} \mathrm{C}$ and the flow of the eluent $\left(12 \mathrm{mM} \mathrm{H}_{2} \mathrm{SO}_{4}\right)$ was constant at $0.6 \mathrm{ml} / \mathrm{min}$. Each sample run lasted 40 min. A spectrophotometer (DR2800, Hach Lange) was used to measure the optical density of liquid samples at $600 \mathrm{~nm}\left(\mathrm{OD}_{600}\right)$ in order to indicate changes in the microbial cells concentration. 


\subsection{Sampling from the Trickle Bed Reactors}

Liquid samples $(2 \mathrm{ml})$ were collected from the liquid sampling ports of the trickle bed reactors on a daily basis and this procedure was combined with equivalent addition of fresh medium in the reactors. The liquid samples were used for the measurement of the OD, the $\mathrm{pH}$ and the VFAs concentration. The composition of the gas phase was also measured on a daily basis offline. A gas-tight syringe was used to collect gaseous samples which were injected in the gas chromatograph for analysis, immediately after collection. During Phase 1 there was no continuous liquid effluent and influent since fresh medium was introduced manually as a pulse. Therefore, the term liquid replacement was used instead of the term hydraulic retention time (HRT).

\subsection{Optical Assessment of Channeling Phenomena in the bed}

After the end of Phase 1, when the positive effect of the liquid recirculation rate on the conversion efficiency of the substrate was observed, an optical test of the distribution of the liquid phase in the column was performed. Fluorescein (Dye content 95\% - Sigma Aldrich) was dissolved in water at a concentration of $1 \mathrm{~g} / \mathrm{l}$ and was inserted in a trickle bed reactor packed with Bioflo 9 packing material identical to the ones in operation. The liquid recirculation rate was gradually increased from 160 to 400 $\mathrm{l} / \mathrm{l}_{\text {bed }} / \mathrm{d}$ (step $80 \mathrm{I} / \mathrm{l}_{\text {bed }} / \mathrm{d}$ ) with the peristaltic pump (Cole Parmer) used in Phase 1 and from 800 to 2000 $\mathrm{I} / \mathrm{I}_{\text {bed }} / \mathrm{d}$ (step $80 \mathrm{I} / \mathrm{I}_{\text {bed }} / \mathrm{d}$ ) with the peristaltic pump (Watson Marlow) used in Phase 2 . The solution of fluorescein was dying with a bright yellow color the paths from which it was trickling through across the bed. The effect of the liquid recirculation rate on the trickle flow regime was optically assessed.

\subsection{Calculation formulas}

The product yields were calculated as moles of electrons assimilated into product i per moles of e- released from the consumption of the energy carriers of the gaseous substrate, $\mathrm{CO}$ and $\mathrm{H}_{2}$. Each mole of $\mathrm{H}_{2}$ carries 2 moles of $\mathrm{e}^{-}\left(n_{e^{-} \mathrm{H}_{2}}=2 e^{-} \mathrm{mol}\right)$ and the same applies for $\mathrm{CO}\left(n_{e^{-} \mathrm{CO}}=2 e^{-} \mathrm{mol}\right)$.

$$
e^{-} \text {yield }_{i}=Y_{i}\left(\frac{e^{-} \text {mol }_{\text {product }}}{e^{-} \text {mol }_{\text {substrate }}}\right)=\frac{n_{(i)} \cdot n_{e^{-}(i)}}{n_{H_{2}} \cdot n_{e^{-} H_{2}}+n_{C O} \cdot n_{e^{-} C O}}
$$


$1 \quad n_{(i)}$ : amount of product $i$ produced in $\left[\frac{\mathrm{mmol}}{l_{\text {bed }} \cdot h}\right]$

$2 \quad n_{\mathrm{H}_{2}}$ : amount of $\mathrm{H}_{2}$ consumed in $\left[\frac{\mathrm{mmol}}{l_{\text {bed }} \cdot h}\right]$

$3 n_{C O}$ : amount of CO consumed in $\left[\frac{\mathrm{mmol}}{l_{\text {bed }} \cdot h}\right]$

$4 \quad n_{e^{-}(i)}$ : moles of electrons fixed per mol of $i$ released $\left[e^{-}\right.$mol $]$

5 For the calculations presented in this work $n_{e^{-}(i)}$ was equal to 8 for $\mathrm{CH}_{4}$ and acetic acid, 14 for propionic

6 acid and 20 for butyric acid.

7 For example, assuming that $5 \mathrm{mmol} / \mathrm{l}_{\text {bed }} / \mathrm{h}$ of $\mathrm{CH}_{4}$ were produced while $30 \mathrm{mmol} / \mathrm{l}_{\text {bed }} / \mathrm{h}$ of $\mathrm{H}_{2}$ and 20

$8 \mathrm{mmol} / \mathrm{l}_{\text {bed }} / \mathrm{h}$ of CO were converted, the yield would be $e^{-}$yield $_{\mathrm{CH}_{4}}=\frac{5 \cdot 8}{30 \cdot 2+20 \cdot 2}=\frac{40}{100}=40 \%$.

9 The conversion efficiency of the gaseous substrates $\mathrm{CO}$ and $\mathrm{H}_{2}$ was calculated as follows, similarly to the 10 removal efficiency in biotrickling filters:

$$
C_{i} \%=\frac{c_{(i)} \text { inflow }-c_{(i)} \text { outflow }}{c_{(i)} \text { inflow }} \%
$$

12 With $c_{(i)}$ expressed in $\left[\frac{\mathrm{mmol}}{l_{\text {bed }} \cdot h}\right]$.

13 The composition of syngas used for substrate was recommended by an external partner as the outflow of a 14 pilot scale biomass gasifier. $\mathrm{CO}_{2}$ is at a high stoichiometric excess and, as a result, its conversion efficiency is 15 not presented in this study. Since $\mathrm{CH}_{4}$ was both a product and a neutral gas in the inflow the amount of $\mathrm{CH}_{4}$ flowing in the reactor was subtracted from the total amount of $\mathrm{CH}_{4}$ flowing out of the reactor in order to calculate the net $\mathrm{CH}_{4}$ production. 
1 Empty Bed Residence Time (EBRT) was defined as the amount of time that the gas would stay in the trickle bed of the reactor assuming an empty bed and no conversion along the bed.

$$
E B R T=\frac{V_{\text {bed }}}{u_{\text {gas }}}(3)
$$

$V_{\text {bed }}:$ Volume of the empty bed $(\mathrm{ml})$

$5 \quad u_{\text {gas }}:$ Gas inflow rate $(\mathrm{ml} / \mathrm{h})$

\section{$6 \quad 2.8$ Set of Experiments pefromed in Phase 1 and Phase 2}

7 Steady state data were collected principally during the two Phases of operation of the bioreactors. The

8 operational parameters for each steady state were chosen in a methodological way so that important

9 information could be extracted regarding their effect on the performance of the bioreactors. In Phase 1 ten

10 steady states were achieved (table 3) studying the consequences of the increase of the Liquid Recirculation

11 Rate and the decrease of the EBRT under a steady liquid replacement of $10 \mathrm{ml} / \mathrm{d}(\mathrm{HRT}=18 \mathrm{~d})$.

Table 3. Operational conditions at which the different steady states were obtained during Phase 1

\begin{tabular}{|c|c|c|c|c|}
\hline $\begin{array}{c}\text { Steady } \\
\text { State } \\
\text { Number }\end{array}$ & Days & $\begin{array}{c}\text { Liquid Replacement } \\
(\mathrm{ml} / \mathrm{d})\end{array}$ & $\begin{array}{c}\text { Liquid Recirculation } \\
\left(\mathrm{l} / \mathrm{l}_{\text {bed }} / \mathrm{d}\right)\end{array}$ \\
\hline 1 & $80-86$ & 10 & 160 & 6 \\
\hline 2 & $87-91$ & 10 & 200 & 6 \\
\hline 3 & $92-99$ & 10 & 240 & 6 \\
\hline 4 & $100-103$ & 10 & 280 & 6 \\
\hline 5 & $104-106$ & 10 & 320 & 6 \\
\hline 6 & $107-111$ & 10 & 320 & 5 \\
\hline 7 & $112-115$ & 10 & 360 & 5 \\
\hline 8 & $116-126$ & 10 & 360 & 4.3 \\
\hline 9 & $127-134$ & 10 & 400 & 4.3 \\
\hline 10 & $135-140$ & 10 & 400 & 3.8 \\
\hline
\end{tabular}

13 

outflow of liquid was initiated.

Table 4. Operational conditions at which the different steady states were obtained during Phase 2

\begin{tabular}{|c|c|c|c|c|}
\hline $\begin{array}{c}\text { Steady State } \\
\text { Number }\end{array}$ & Days & HRT $(\mathrm{d})$ & $\begin{array}{c}\text { Liquid Recirculation } \\
\left(\mathrm{l} / \mathrm{l}_{\text {bed }} / \mathrm{d}\right)\end{array}$ & EBRT (h) \\
\hline 11 & $166-176$ & 5.5 & 1600 & 3.00 \\
\hline 12 & $177-179$ & 5.5 & 1600 & 2.73 \\
\hline 13 & $180-181$ & 5.5 & 1600 & 2.50 \\
\hline 14 & $182-194$ & 5.5 & 1600 & 2.31 \\
\hline 15 & $195-201$ & 5.5 & 1600 & 2.14 \\
\hline 16 & $202-206$ & 5.5 & 1600 & 2.00 \\
\hline 17 & $207-211$ & 5.5 & 1600 & 1.88 \\
\hline 18 & $212-216$ & 5.5 & 1600 & 3.25 \\
\hline 19 & $217-225$ & 11 & 1600 & 3.25 \\
\hline 20 & $228-249$ & 11 & 1600 & 1.83 \\
\hline 21 & $250-270$ & 5.5 & 1600 & 1.83 \\
\hline 22 & $271-282$ & 4.4 & 1600 & 1.46 \\
\hline 23 & $283-290$ & 3.7 & 1600 & 1.46 \\
\hline 24 & $291-297$ & 3.7 & 2000 & 1.46 \\
\hline
\end{tabular}

4

5

\section{Results and Discussion}

\subsection{Results}

\subsubsection{Reactors start-up}

Before the initiation of the experiments, the two reactors were flushed with syngas for 4 hours in order to establish an anoxic environment. The reactors were then inoculated with enriched mixed mesophilic methanogenic anaerobic consortia in a total liquid volume of $180 \mathrm{ml}$ (60 ml inoculum and $120 \mathrm{ml}$ medium). The liquid recirculation rate was set at $20 \mathrm{ml} / \mathrm{min}$ or $160 \mathrm{l} / \mathrm{l}_{\text {bed }} / \mathrm{d}$ and the syngas flow rate at $10 \mathrm{ml} / \mathrm{min}(0.3$ h EBRT) in order to maintain a high amount of gas supply and thus to secure a fast growth of microbes and potentially a faster biofilm formation on the packing material. When microbial growth was observed in the liquid phase a $5 \mathrm{ml} / \mathrm{d}$ liquid replacement (manually drawn and injected) with fresh medium was initiated. The $\mathrm{pH}$ was not controlled. The results for the 44 days of operation after inoculation are presented in Fig. 2. 
1 Initially a three days lag phase was observed which was succeeded by a fast rise of the concentration of the

2 cells in the liquid phase with a simultaneous production of acetic acid. This resulted in a fast drop of the $\mathrm{pH}$

3 below 6 which is unfavorable for methanogenesis. Production of $\mathrm{CH}_{4}$ could not be determined during this

4 startup phase due to the high gas inflow rate masking any differences of $\mathrm{CH}_{4}$ composition between influent

5 and effluent gas streams.

6 On day 15, the liquid broth of the reactor was diluted 5 times with fresh medium, so as to increase the $\mathrm{pH}$

7 and a manual $10 \mathrm{ml} / \mathrm{d}$ replacement of the liquid with fresh medium was continued. The syngas flow was

8 decreased to $5 \mathrm{ml} / \mathrm{min}$. However, $\mathrm{CH}_{4}$ production was still undetectable due to the high methane inflow

9 rate. It was obvious that the increase of the daily liquid replacement volume of the medium decreased the

10 rate of $\mathrm{pH}$ drop but it was not enough to maintain the $\mathrm{pH}$ at high enough levels (close to 7) for optimal

11 growth of methanogens.

12 The observed increase of acetic acid indicated that under these operating conditions acetogenic bacteria

13 produced it at higher rates than the methanogens could consume it. The formation of biofilm on the

14 packing material was visible after 20 days of operation but only on specific positions within the bed of the

15 bioreactors where liquid was flowing through. This phenomenon is known as channeling and is a challenge

16 with this kind of setups where liquid is not flowing uniformly through the packed bed due to the geometry

17 of the packing material. 

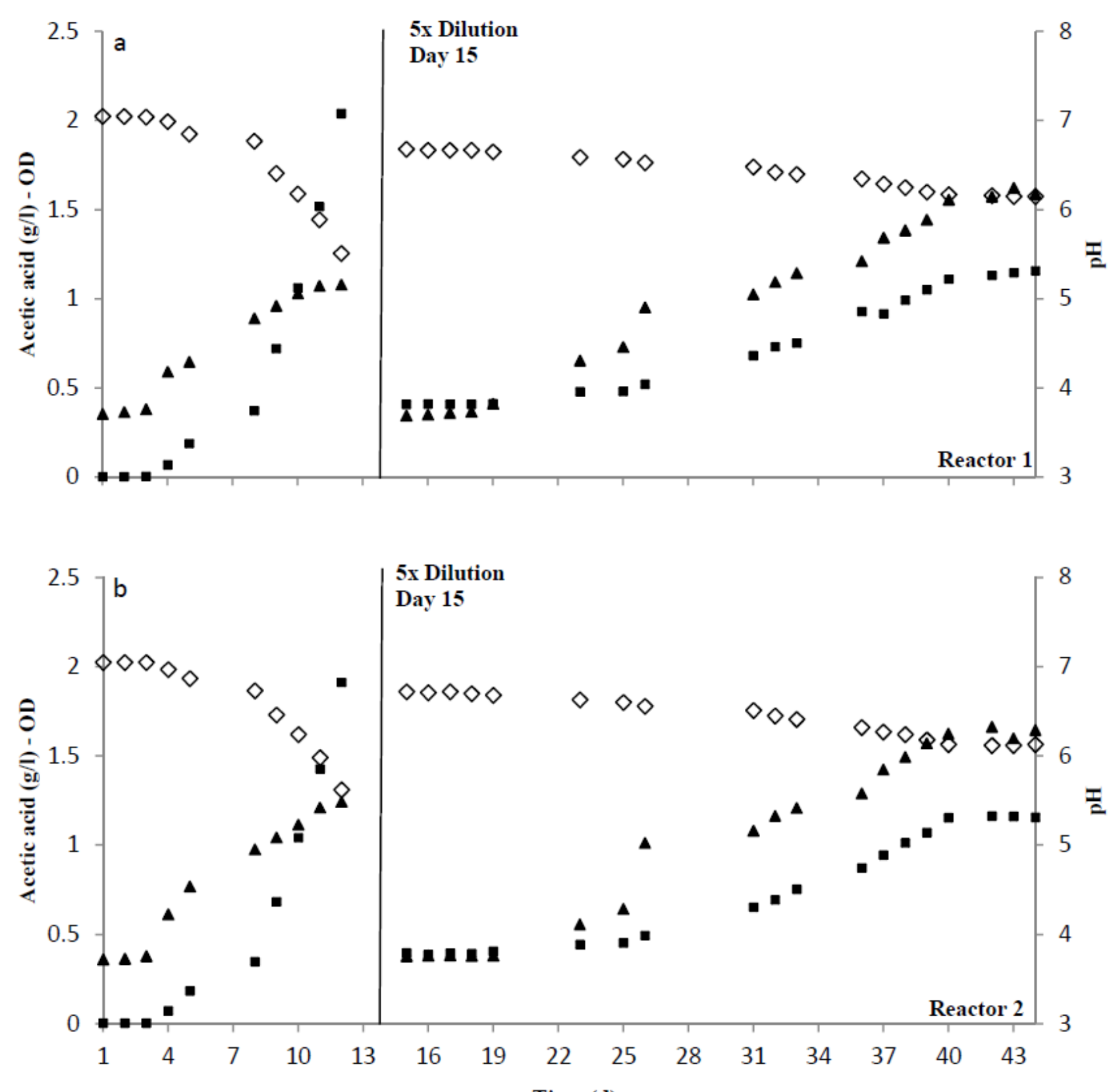

Time (d)

- Acetic acid $\Delta \mathrm{OD} \diamond \mathrm{pH}$

\section{Figure 2. Development of $\mathrm{OD}_{600}$, acetic acid concentration and pH for the 44 first days of the 2 bioreactors' operation. Upper} chart (a) refers to Reactor 1 and lower chart (b) refers to Reactor 2

\section{$4 \quad 3.1 .2$ Change of the buffering capacity of the medium}

5 On day 44, the reactors were emptied of the liquid broth and they were reinoculated with fresh enriched

6 anaerobic culture in a total liquid volume of $180 \mathrm{ml}(120 \mathrm{ml}$ medium and $60 \mathrm{ml}$ inoculum) in order to secure

7 growth of all the microbial groups including those that could have been inhibited and washed out during

8 the period the $\mathrm{pH}$ was too low. The reactors were operated under batch mode in terms of the liquid but 
under continuous gas supply at a flow of $0.5 \mathrm{ml} / \mathrm{min}$ for the next 15 days. On day 60 , the reactors' total VFAs concentration was $1.32 \mathrm{~g} / \mathrm{l}$ for Reactor 1 and $1.43 \mathrm{~g} / \mathrm{l}$ for Reactor 2 corresponding to $\mathrm{pH}$ values of 6.1 and 6.0 respectively. On the same day the low syngas inflow rate allowed us to document for the first time $\mathrm{CH}_{4}$ productivity at $0.15 \mathrm{mmol} / \mathrm{l}_{\text {bed }} / \mathrm{h}$ and $0.19 \mathrm{mmol} / \mathrm{l}_{\text {bed }} / \mathrm{h}$ respectively.

Between day 60 and day 80, it was attempted to establish a medium with a strong buffering capacity able to withhold the $\mathrm{pH}$ close to a value of 7 without causing inhibitory effects to the microorganisms. Solution $\mathrm{B}$ used for the medium preparation was finally modified to $\mathrm{K}_{2} \mathrm{HPO}_{4}$ and $\mathrm{KH}_{2} \mathrm{PO}_{4}$ concentrations of $87 \mathrm{mM}$ and $13 \mathrm{mM}$ in the medium, respectively. The medium with the stronger buffering capacity was applied on day 73. This resulted in a steady rise of the $\mathrm{pH}$ of the reactors to $6.7-6.8$ after 7 days of operation.

\subsubsection{Operation of the reactors under steady state conditions - Phase 1}

From day 80 and until day 140 (the end of Phase 1), ten different steady states were reached (table 3) under a constant daily liquid replacement of $10 \mathrm{ml}$. The two operational parameters that were manipulated were the liquid recirculation rate and the EBRT (by changing the gas inflow rate).

Increasing the liquid recirculation rate from steady state 1 up to steady state 5 resulted in higher $\mathrm{CH}_{4}$ productivity and higher conversion efficiencies of $\mathrm{H}_{2}$ and $\mathrm{CO}$ in both reactors (Fig. 3). In Reactor 1 , when the liquid recirculation rate was doubled from $160 \mathrm{I} / \mathrm{l}_{\text {bed }} / \mathrm{d}$ to $320 \mathrm{I} / \mathrm{I}_{\text {bed }} / \mathrm{d}$, the $\mathrm{CH}_{4}$ productivity increased from $0.47 \mathrm{mmol} / \mathrm{l}_{\text {bed }} / \mathrm{h}$ at steady state 1 to $0.62 \mathrm{mmol} / \mathrm{l}_{\text {bed }} / \mathrm{h}$ at steady state 5 , while the conversion efficiencies of $\mathrm{H}_{2}$ and $\mathrm{CO}$ increased from $69 \%$ and $63 \%$ to $80 \%$ and $71 \%$, respectively. The same effect was observed when the liquid recirculation rate was increased at lower EBRTs between steady state 6 and steady state 7 as well as between steady state 8 and steady state 9 . The increase of the liquid recirculation rate decreased the magnitude of the channeling phenomena within the bed. Higher liquid recirculation rates resulted in a more uniform trickling of the liquid through the packed column as well as a more uniform wetting of the packing material and as a result the potential spots for biofilm formation were increased. Comparing steady state 5 with 6,7 with 8 , and 9 with 10, it can be seen that an increase of the $\mathrm{CH}_{4}$ productivity was observed 
1 when the gas inflow rate increased. Nevertheless, this should also be seen from a conversion efficiency

2 point of view. The conversion efficiency of $\mathrm{H}_{2}$ and $\mathrm{CO}$ decreased when the gas inflow rate increased, which

3 indicated that the biofilm was close to its maximum substrate uptake rate, allowing thus a higher

4 percentage of the gas influent to pass through the trickle bed unconverted. For example, in Reactor $2 \mathrm{a}$

5 decrease of the EBRT from $6 \mathrm{~h}$ to $5 \mathrm{~h}$ between steady state 5 and 6 led to an increase of the $\mathrm{CH}_{4}$

6 productivity from $0.64 \mathrm{mmol} / \mathrm{l}_{\text {bed }} / \mathrm{h}$ to $0.72 \mathrm{mmol} / \mathrm{l}_{\text {bed }} / \mathrm{h}$, while the conversion efficiencies of $\mathrm{H}_{2}$ and $\mathrm{CO}$

7 dropped from $82 \%$ and $72 \%$ to $75 \%$ and $63 \%$, respectively. Therefore, the higher $\mathrm{CH}_{4}$ productivity rate

8 occurred at a cost of a lower content of $\mathrm{CH}_{4}$ in the outflow gas and a concomitant higher percentage of $\mathrm{H}_{2}$

9 and $\mathrm{CO}$. 


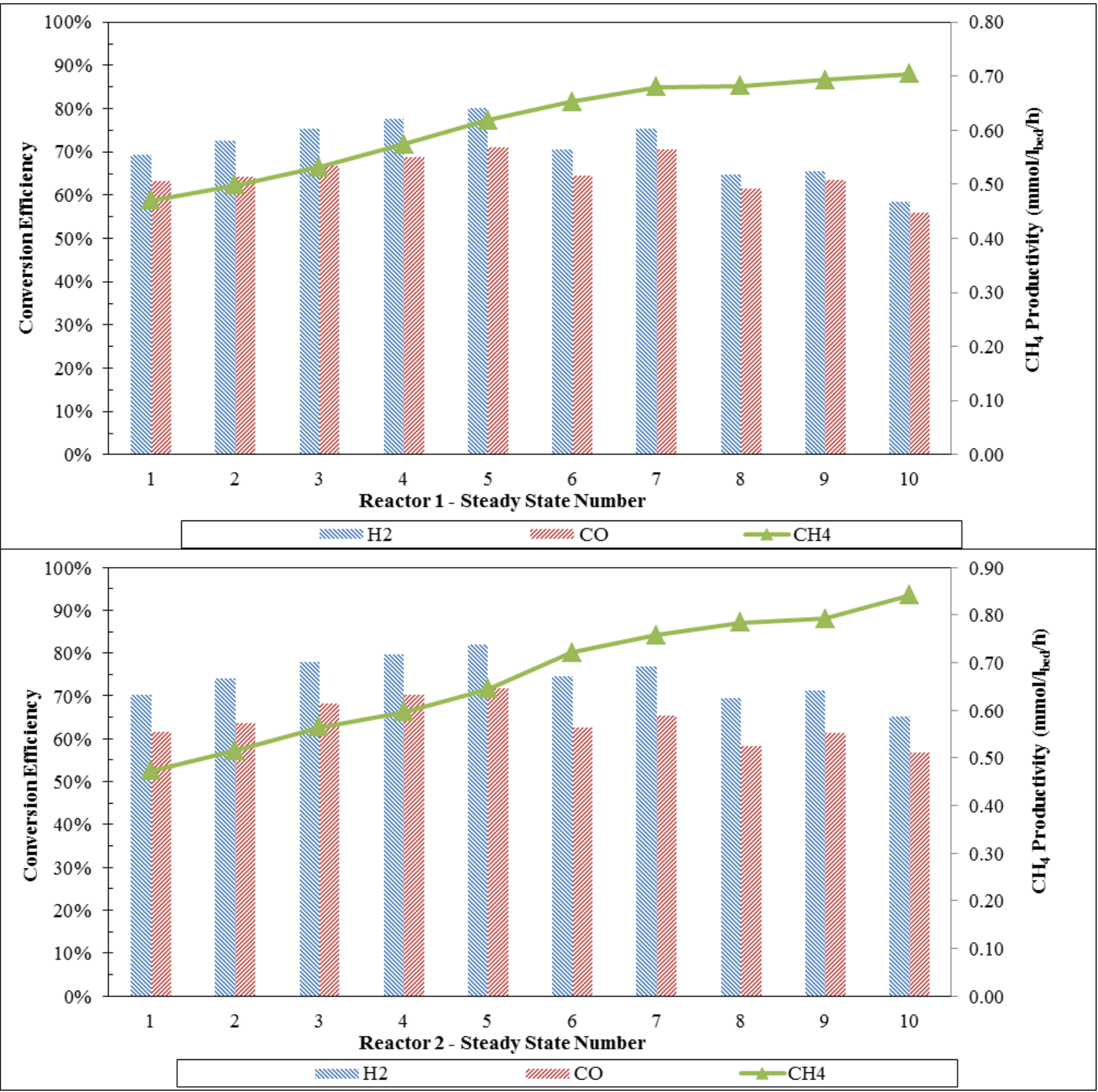

2 Figure 3. Conversion efficiency of $\mathrm{H}_{2}$ and $\mathrm{CO}$ and productivity of $\mathrm{CH}_{4}$ for the first 10 steady states

3 By calculating the moles of $\mathrm{e}^{-}$released from the conversion of $\mathrm{CO}$ and $\mathrm{H}_{2}$ and how these $\mathrm{e}^{-}$moles were

4 distributed to the products, it may be observed in Fig. 4 that in both reactors more than $60 \%$ of the

5 released moles of $\mathrm{e}^{-}$were utilized for $\mathrm{CH}_{4}$ production while $20 \%$ to $25 \%$ were used for the production of

6 VFAs from acetogenic bacteria in each steady state. The maximum $\mathrm{CH}_{4}$ e-yield was $77 \%$ and was achieved in

7 Reactor 1 at steady state 6 . The unidentified part of the e moles fixation can be attributed to microbial

8 growth and maintenance as well as other low concentration byproducts which were not detected. 


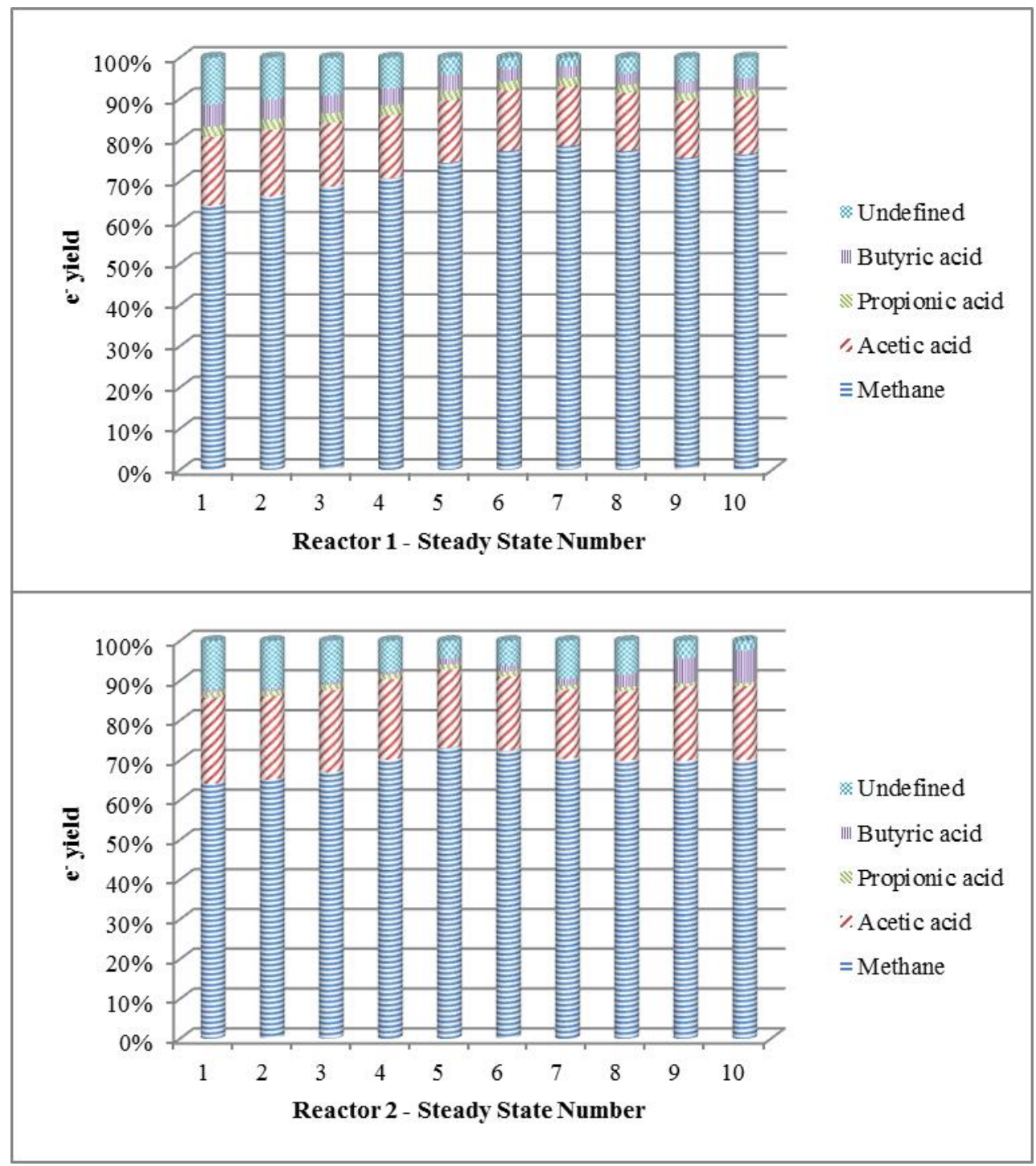

Figure 4. Product yields expressed in terms of moles of electrons incorporated to the products per total moles of electrons released by the conversion of carbon monoxide and hydrogen as observed during experimental Phase 1

3.1.4 Operation of the reactors under steady state conditions - Phase 2

7 From Day 140 till Day 168 the reactors were in maintenance and important adjustments took place in order

8 to further improve the substrate uptake potential of the microbes and to establish a continuous mode for

9 the liquid phase. On Day 145 the peristaltic pump used for the recirculation of the liquid to the top of the

10 trickle bed column was replaced with one that could achieve higher flow rates and the pumping speed was at $1600 \mathrm{I} / \mathrm{I}_{\text {bed }} / \mathrm{h}$ so as to further limit the observed channeling phenomena. In addition, a pumping system was installed for the continuous inflow of fresh medium and outflow of liquid broth, as it is pointed out in 
1 Fig. 1. (parts $11-14)$. Furthermore, it was observed that the concentration of the trace metals was a

2 limiting factor for the growth of the microbial communities on the biofilm at higher gas inflow rates and as

3 a result it was increased 2.5 times to the level that it was sufficient without causing any inhibitory effects.

4 The tests for the effects of the trace metals' concentration in the medium were performed only in Reactor

51 so as to secure that the $2^{\text {nd }}$ reactor could still operate in case of process failure from trace metal inhibition.

6 The results showed a rise a of the conversion efficiency of $\mathrm{H}_{2}$ and $\mathrm{CO}$ from $66 \%$ and $57 \%$ to $91 \%$ and $83 \%$,

7 respectively. This was accompanied by a significant increase of the microbial cells concentration in the

8 liquid phase from $0.231 \mathrm{~g} / \mathrm{l}$ to $0.326 \mathrm{~g} /$ (indicating increased biofilm growth), an increase of the $\mathrm{CH}_{4}$

9 productivity from $1.35 \mathrm{mmol} / \mathrm{I}_{\text {bed }} / \mathrm{h}$ to $1.61 \mathrm{mmol} / \mathrm{I}_{\text {bed }} / \mathrm{h}$ and a slight increase of the concentration of acids

10 from $1.49 \mathrm{~g} / \mathrm{l}$ to $1.61 \mathrm{~g} / \mathrm{l}$. When the positive effect was observed on Reactor 1 the same medium started

11 being used for Reactor 2 which presented the same behavior as Reactor 1.

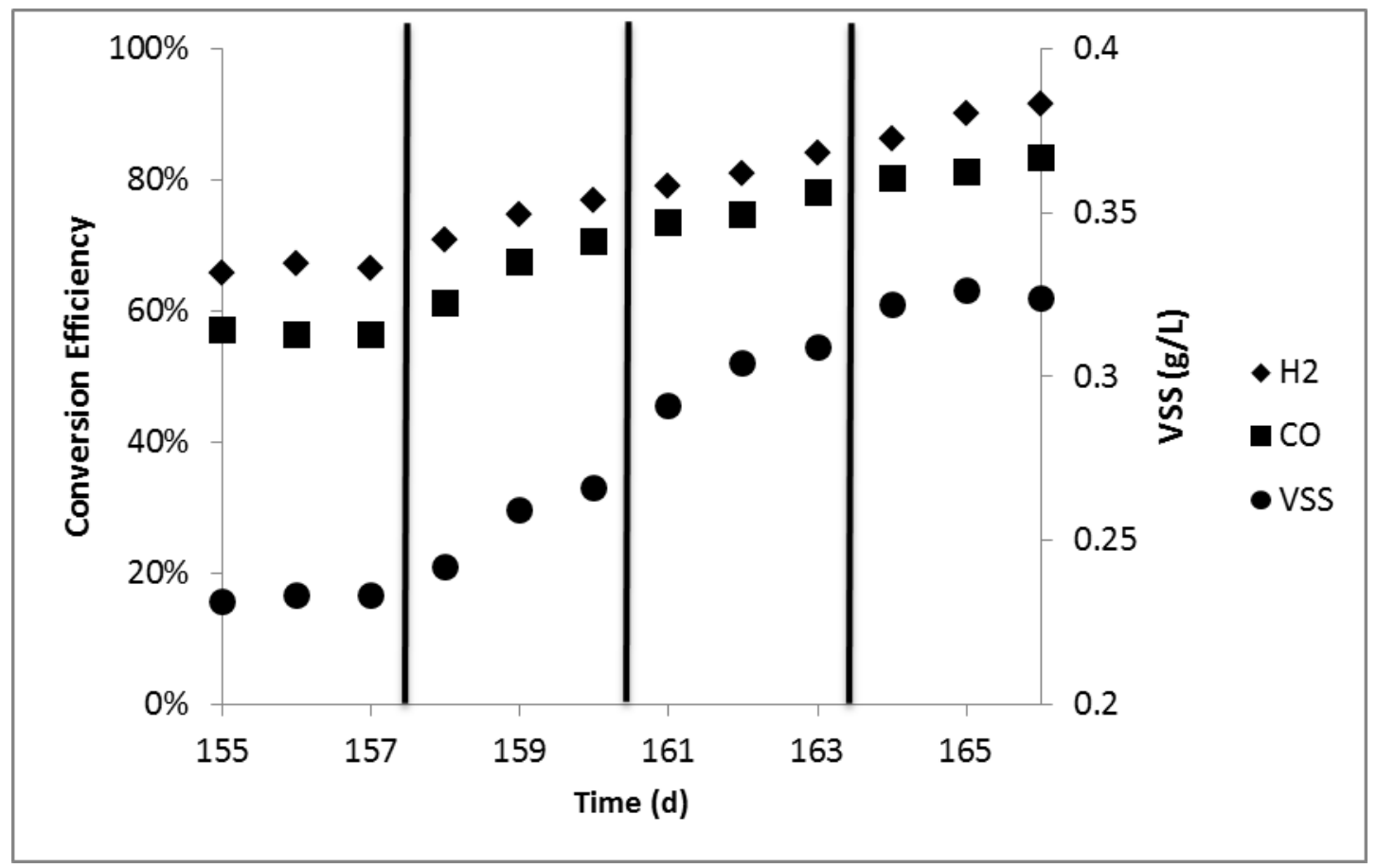

Figure 5. Effect of trace metals' concentration on the conversion efficiency of the substrate and the concentration of VSS in the liquid reservoir. The experiment was performed at 8 days HRT and 3 hours EBRT. TM: Concentration of Trace Metals, x1: initial concentration as described in Section 2.2 
1 The reactors were operated from Day 168 till Day 297 (Phase 2) with the applied modifications. During this time period 14 steady states were obtained and the values of the operational parameters are presented in Table 4.

From steady state 11 till steady state 17 the HRT and the liquid recirculation rate remained stable while the gas inflow rate was gradually increased so as to examine down to what level of EBRT the biofilm could consume the available substrate. From the results presented in Fig. 6 it is deduced that down to an EBRT of $2.31 \mathrm{~h}$ the conversion efficiency of $\mathrm{H}_{2}$ was constantly above $90 \%$ while the conversion efficiency of CO was above $80 \%$. From steady State 15 up to steady State 17 the conversion efficiency of the substrate dropped with the EBRT due to the fact that the biofilm had reached its maximal uptake potential. On steady state 18 the increase of the EBRT to $3.33 \mathrm{~h}$ led to a conversion efficiency of $\mathrm{H}_{2}$ and $\mathrm{CO}$ higher than $90 \%$ while $\mathrm{CH}_{4}$ productivity dropped due to the low inflow rate of substrate (syngas). In addition, the percentage of $\mathrm{CH}_{4}$ at the exit of reactor 1 increased from $24 \%$ at steady state 17 to $38 \%$ and the percentage of $\mathrm{H}_{2}$ and CO dropped below $10 \%$ (table 5).

On steady state 19 the HRT was increased to 11 days and although no significant effect was noticed on the conversion efficiency of the substrate, an important decrease on the e yield to VFAs was observed (Fig. 7) in both reactors while the e- yield to $\mathrm{CH}_{4}$ remained unaffected. When the HRT was increased the rate of the nutrients inflow was decreased proportionally and since the gas inflow rate remained the same it is possible that specific nutrients necessary for the acidogenic metabolism in the already existing biofilm were depleted. Moreover, the $\mathrm{CH}_{4}$ content reached its maximum value at the exit of the reactor ( $38 \%$ for reactor 1 and 39\% for reactor 2) while $\mathrm{CO}$ and $\mathrm{H}_{2}$ had their minimum values from all the steady states tested. On steady state 20 the gas inflow rate was increased to the levels of steady state 17 while the HRT remained at 11 days resulting in a slightly lower $\mathrm{CO}$ conversion efficiency and $\mathrm{CH}_{4}$ productivity than steady state 17. However, when on steady state 21 the HRT was drastically decreased to the level of steady state 17 the $\mathrm{H}_{2}$ and $\mathrm{CO}$ conversion efficiencies dropped along with the $\mathrm{CH}_{4}$ productivity. This is a consequence of the fact 
1 that steep changes in the HRT of the trickle bed reactors cannot be followed by fast enough changes of the

2 biofilm structure and microbial composition potentially resulting in the opposite effects than expected. A

3 simultaneous decrease on the EBRT and the HRT was applied during steady state 22 and the efficiencies of

4 the two reactors recovered. However, the reactors behaved for the first time differently. While in both

5 reactors the conversion efficiency of the substrate was in the same levels, the distribution of the energy

6 released in the form of electrons differentiated; in Reactor $120 \%$ of the electrons were fixed into VFAs

7 while in Reactor 2 this was only 10\%, thus allowing for more energy to be available for methanogenesis. On

8 steady state 24 though, when the liquid recirculation rate increased to $250 \mathrm{ml} / \mathrm{min}$ the two reactors

9 produced the same results showing that the deviation between them was just transient. Overall, the two

10 reactors run independently but under the same operational parameters for almost 300 days and they

11 presented almost identical behavior, pointing out an adequate reproducibility of the process. This is a

12 compelling element since use of mixed microbial consortia and reproducibility of results has been

13 questioned due to the complexity of their diverse nature [41].

Table 5. Composition of the produced gas at the exit of the reactor during Phase 2

\begin{tabular}{|c|c|c|c|c|c|c|c|c|}
\hline & \multicolumn{2}{|c|}{$\mathrm{H}_{2}(\%)$} & \multicolumn{2}{c|}{$\mathrm{CO}(\%)$} & \multicolumn{2}{c|}{$\mathrm{CO}_{2}(\%)$} & \multicolumn{2}{c|}{$\mathrm{CH}_{4}(\%)$} \\
\hline $\begin{array}{c}\text { Steady } \\
\text { State } \\
\text { Number }\end{array}$ & Reactor 1 & Reactor 2 & Reactor 1 & Reactor 2 & Reactor 1 & Reactor 2 & Reactor 1 & Reactor 2 \\
\hline 11 & $9 \%$ & $13 \%$ & $8 \%$ & $15 \%$ & $50 \%$ & $42 \%$ & $33 \%$ & $30 \%$ \\
\hline 12 & $9 \%$ & $12 \%$ & $8 \%$ & $10 \%$ & $51 \%$ & $47 \%$ & $32 \%$ & $31 \%$ \\
\hline 13 & $10 \%$ & $11 \%$ & $8 \%$ & $9 \%$ & $52 \%$ & $49 \%$ & $31 \%$ & $32 \%$ \\
\hline 14 & $13 \%$ & $11 \%$ & $10 \%$ & $7 \%$ & $49 \%$ & $50 \%$ & $28 \%$ & $33 \%$ \\
\hline 15 & $14 \%$ & $13 \%$ & $10 \%$ & $8 \%$ & $48 \%$ & $48 \%$ & $28 \%$ & $31 \%$ \\
\hline 16 & $16 \%$ & $15 \%$ & $11 \%$ & $10 \%$ & $47 \%$ & $48 \%$ & $26 \%$ & $28 \%$ \\
\hline 17 & $19 \%$ & $20 \%$ & $13 \%$ & $13 \%$ & $44 \%$ & $43 \%$ & $24 \%$ & $24 \%$ \\
\hline 18 & $7 \%$ & $10 \%$ & $7 \%$ & $10 \%$ & $48 \%$ & $43 \%$ & $38 \%$ & $37 \%$ \\
\hline 19 & $6 \%$ & $8 \%$ & $6 \%$ & $7 \%$ & $50 \%$ & $46 \%$ & $38 \%$ & $39 \%$ \\
\hline 20 & $18 \%$ & $20 \%$ & $13 \%$ & $17 \%$ & $45 \%$ & $40 \%$ & $24 \%$ & $23 \%$ \\
\hline 21 & $25 \%$ & $24 \%$ & $21 \%$ & $18 \%$ & $34 \%$ & $37 \%$ & $20 \%$ & $21 \%$ \\
\hline 22 & $22 \%$ & $21 \%$ & $15 \%$ & $13 \%$ & $41 \%$ & $44 \%$ & $22 \%$ & $22 \%$ \\
\hline 23 & $21 \%$ & $24 \%$ & $14 \%$ & $15 \%$ & $43 \%$ & $40 \%$ & $22 \%$ & $21 \%$ \\
\hline 24 & $22 \%$ & $21 \%$ & $15 \%$ & $15 \%$ & $41 \%$ & $41 \%$ & $22 \%$ & $23 \%$ \\
\hline
\end{tabular}

15 


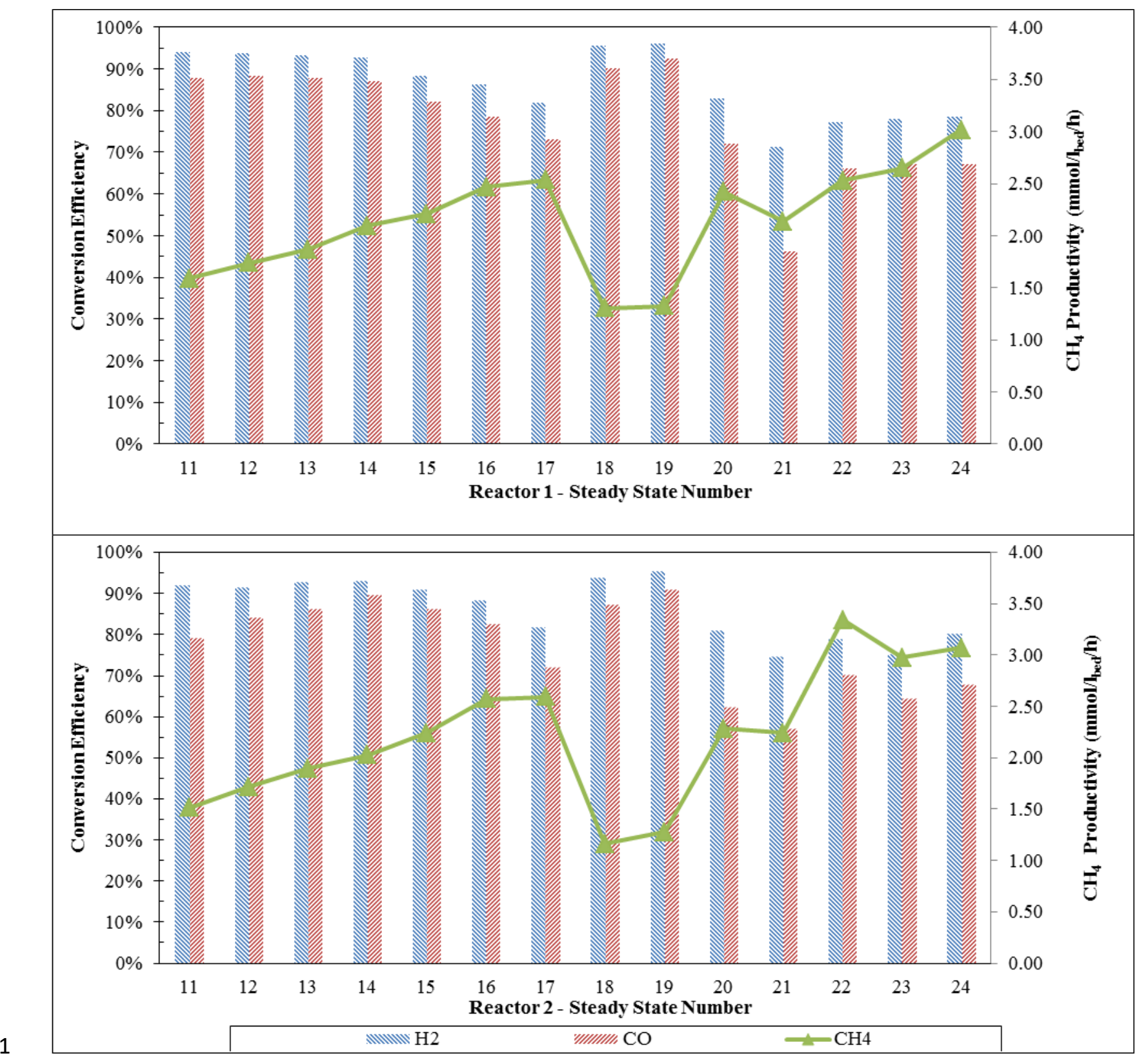

Figure 6. Conversion efficiency of $\mathrm{H}_{2}$ and $\mathrm{CO}$ and productivity of $\mathrm{CH}_{4}$ for the steady states of Phase 2 


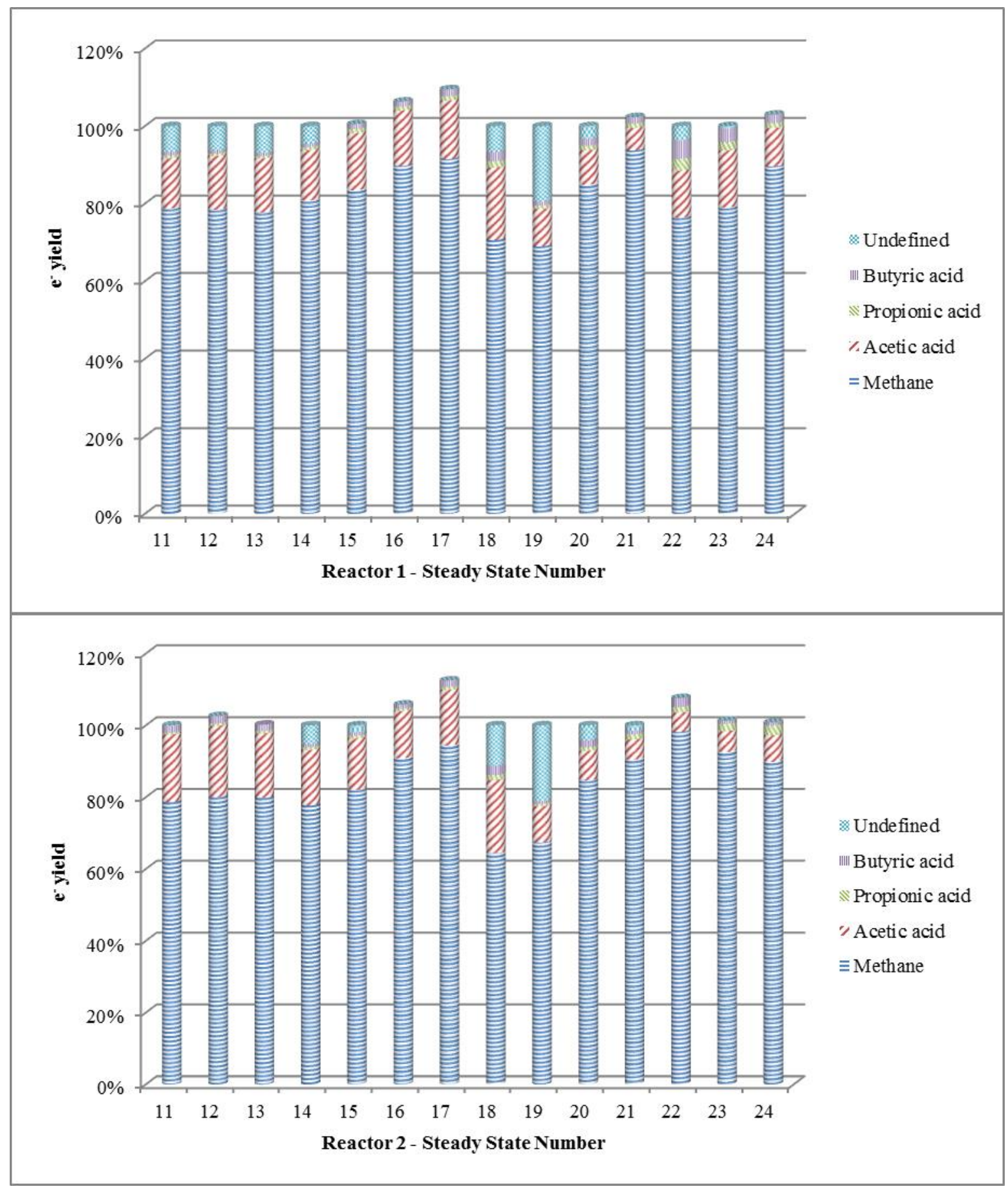

2 Figure 7. Product yields expressed in terms of moles of electrons incorporated to the products per total moles of electrons released by the conversion of carbon monoxide and hydrogen during Phase 2.

\section{$4 \quad 3.2$ Discussion}

$5 \quad 3.2 .1$ Production of VFAs and their effect on syngas biomethanation

6 The accumulation of acetic acid during the start-up of the reactors indicated that the acetoclastic

7 methanogens could not consume it fast enough in order to balance its production from the fast growing 
acetogens. The same observation was made by Rachbauer et al. [31] when they initiated their experimental trickle bed reactor for biogas upgrade. It is also well established that high partial pressures of CO reduces the methanogenic activity [42] of mixed microbial consortia and that the $\mathrm{CO}$ dehydrogenase of acetogens has higher affinity for CO than the one of methanogens [43]. Esquivel et al. [44] assessed the impact of CO on methanogenesis under batch conditions on anaerobic sludge and at CO partial pressures $\geq 0.11$ atm they estimated partial inhibition of the methanogens with simultaneous accumulation of acetic acid. In addition, adverse effects on methanogenesis of $\mathrm{H}_{2} / \mathrm{CO}_{2}$ have been reported by acetic acid concentrations as low as $1.2 \mathrm{~g} / \mathrm{l}[45]$. Therefore, it is of vital importance to maintain the acetic acid concentration at low levels during 9 syngas biomethanation. For the examined process configurations in the present study, where no $\mathrm{pH}$ control was applied, the accumulation of acids resulted in a fast $\mathrm{pH}$ drop to inhibitory levels for the methanogenic archaea. In addition, it is well documented that changes on the $\mathrm{pH}$ of the microbial environment cause alterations on the intracellular $\mathrm{pH}$ and the electrochemical gradient across the membrane of the microbes, thus, influencing their metabolism and their bioenergetics [15]. Since the size of the reactors did not allow pH control and in order to alleviate the negative effects of acetogenesis, it was necessary to increase the buffering capacity in the medium. This was achieved by adding a $\mathrm{K}_{2} \mathrm{HPO}_{4} / \mathrm{KH}_{2} \mathrm{PO}_{4}(87 \mathrm{mM} / 13 \mathrm{mM})$ buffer in the medium which resulted in maintaining the $\mathrm{pH}$ at high enough values for the growth of methanogens. Nonetheless, the addition of a high phosphate concentration buffer is not recommended for full scale plants. An additional measure, applied during Phase 2, was the use of low HRTs which was linked to the sufficient provision of nutrients for microbial growth. The concentrations of acetate, propionate and butyrate (which were the only VFAs detected at significant concentration) in the reactors are presented in Fig. 8 along with the $\mathrm{pH}$ values. It is evident that the $\mathrm{pH}$ was rather stable during the experiments with small fluctuations which could not have a serious effect on the performance of the methanogens. 
1 VFAs production from mixed microbial consortia performing syngas biomethanation and biogas upgrade

2 has also been reported under thermophilic and extreme-thermophilic conditions [46, 47]. Strubing et al. [34]

3 performed biological methanation of $\mathrm{CO}_{2}$ in a trickled bed reactor at $55^{\circ} \mathrm{C}$ and experienced significant

4 reduction of $\mathrm{H}_{2}$ conversion when no $\mathrm{pH}$ control was applied due to the activity of homoacetogenic bacteria.

5 Kougias et al. [48] further investigated the causes of the occurred acetate accumulation in thermophilic

6 anaerobic bioreactors performing $16 \mathrm{~S}$ rRNA sequencing of the microbiome. They observed a high

7 population of homoacetogenic species and hydrogenotrophic methanogens but no presence of acetoclastic

8 methanogens. 

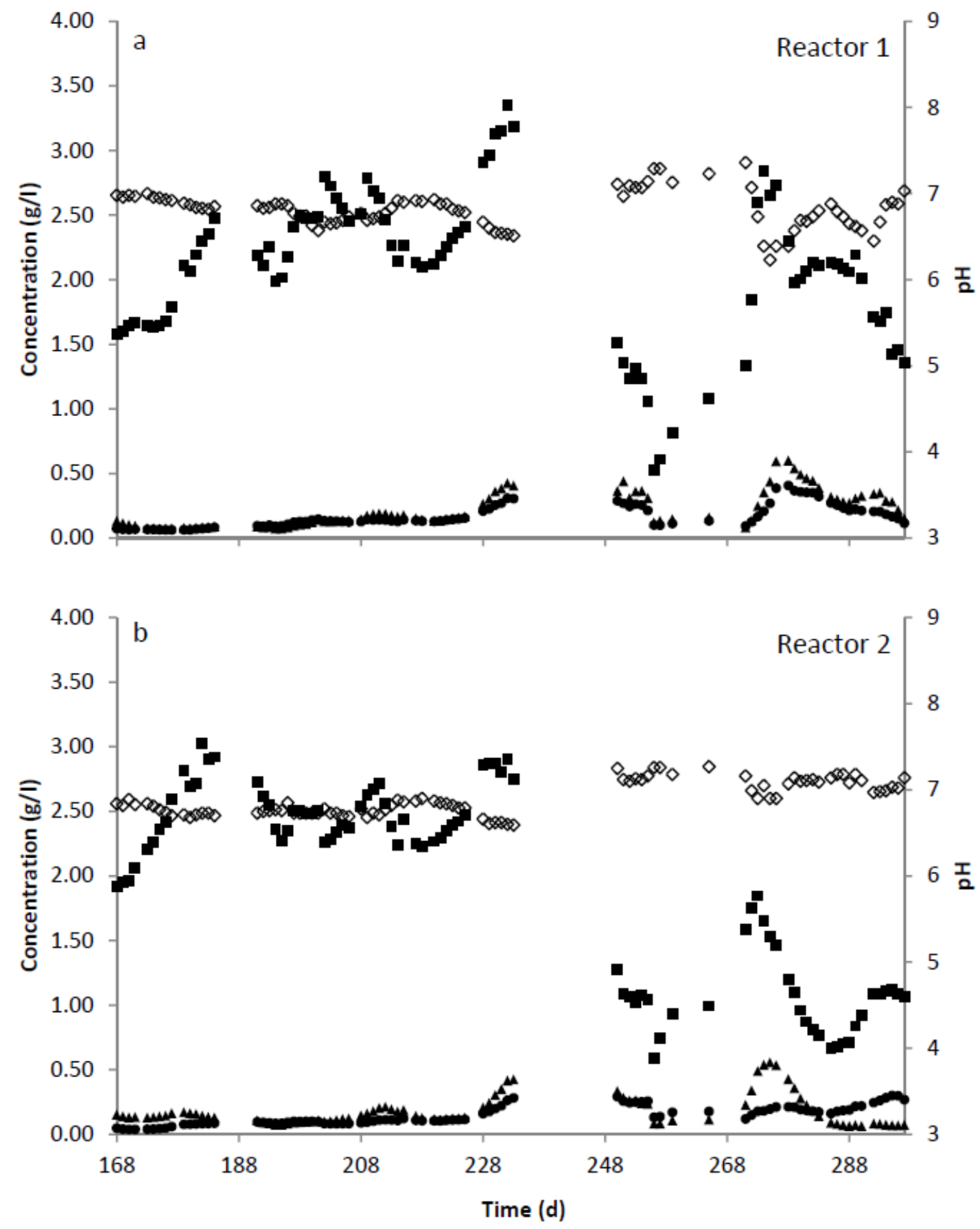

- Acetic acid • Propionic acid $\Delta$ Butyric acid $\diamond \mathrm{pH}$

2 Figure 8. Distribution of VFAs concentration and pH in the reactors for the second phase of the experiments. Upper chart (a) 3 refers to Reactor 1 and lower chart (b) refers to Reactor 2

$5 \quad 3.2 .2$ Effect of the Liquid Recirculation Rate on Biofilm Formation

6 An important factor affecting significantly the performance of the bioreactors during Phase 1 was the liquid

7 recirculation rate. It was visible that when a low liquid recirculation rate was applied, the liquid was 
1 trickling down the bed through specific narrow paths leaving a part of the bed dry. Thus, the available surface area for biofilm formation was limited significantly. In order to evaluate the effect of the liquid recirculation rate on the conversion efficiency of the substrate a progressive increase was applied from steady state 1 till steady state 5 (Fig. 3). The results showed a linear increase of the substrate uptake and finally at steady state 10 it could be clearly seen that the biofilm was covering the entire length of the bed. Further increasing the liquid recirculation rate up to $1600 \mathrm{I} / \mathrm{I}_{\text {bed }} / \mathrm{d}$ on Phase 2 resulted in an even bigger expansion of the biofilm, which was visually detected, compared to Phase 1 . This observation was verified also from the flow of $1 \mathrm{~g} / \mathrm{l}$ fluorescein solution across the column at step-wise increased liquid recirculation rates (section 2.6). As the flow was increasing from 160 to $1600 \mathrm{l} / \mathrm{I}_{\text {bed }} / \mathrm{d}$, a higher fraction of the bed was dyed. Above $1600 \mathrm{I} / \mathrm{l}_{\text {bed }} / \mathrm{d}$ no significant increase of the dyed area in the bed was visually observed. Kimmel et al. [29] also observed an increase in the conversion efficiency of CO when they operated their trickle bed reactor at higher liquid recirculation rates. The effect of the liquid distribution on the trickle flow regime has been addressed by Mederos et al [49] (in general and not for biomethanation of syngas though) and several factors (such as the construction of the bed, the size and the geometry of the packing material and the manner the liquid and the gas are introduced in the reactor) have been demonstrated to hinder an ideal plug flow. A major bottleneck of trickle bed bioreactors or biotrickling filters is bioclogging, namely the accumulation of biomass in the packed bed resulting in an undesired rise of the pressure drop across the column [50]. This phenomenon was not present in this study since the organic loading rate introduced in syngas fermentation is not high enough to establish a very thick biofilm while the concentration of VSS did not surpass the value of $0.6 \mathrm{~g} / \mathrm{l}$.

The minimization of the negative effects of channeling phenomena is crucial when scaling up the setup since $1600 \mathrm{I} / \mathrm{l}_{\text {bed }} / \mathrm{d}$ is not a feasible flow. A higher diameter and thus a larger bed volume is expected to decrease the wall effect since most of the liquid flow would be able to trickle down through the bed without coming in contact with the wall of the column. In addition, dedicated devices such as nozzles would 
1 be employed for the introduction of the liquid in the top of the column so as to improve the distribution of the liquid amongst the packing material.

\subsubsection{Effect of the Gas Inflow Rate on Syngas Biomethanation}

The gas inflow rate constitutes an indication of the substrate uptake potential of the formed biofilm. High gas inflow rates usually lead a system to be mass transfer limited since there is not enough time for the liquid phase surrounding the biofilm to get saturated on the gaseous compounds [51]. On the other hand low gas inflow rates can designate kinetic limitations of the system if any exist [51]. Increasing the gas (substrate) inflow rate can indicate the point where the system has reached its maximum conversion capacity. That is, when the conversion efficiency of the available substrate has reached a maximum (for the applied operating conditions). Further increase of the gas inflow rate will result in a drop of the conversion efficiency and as a consequence, the $\mathrm{CH}_{4}$ content of the gas exiting the reactor will decrease. This is what happened on the transition from steady state 14 to steady state 15 and up to steady state 17 (Fig. 6). Dependent on the desired outcome regarding the $\mathrm{CH}_{4}$ content of the produced gas, the gas inflow rate can act as an optimization objective. Therefore for the case of the present study, if the target was set on maximizing the $\mathrm{CH}_{4}$ content of the effluent gas the optimal operational choice would be steady state 14 or steady state 19 . On the other hand, if the target was set on maximizing the $\mathrm{CH}_{4}$ productivity (amount of methane produced per reactor volume and time) then the optimal choice would be steady state 24 for the first reactor and steady state 22 for the second. Compared to biotrickling filters that deal with volatile organic compounds under aerobic conditions and have EBRTs lower than two minutes [51], reported EBRTs for syngas fermentation surpass the two hours (table 6) indicating the adverse nature of this anaerobic process.

\subsubsection{Comparison with literature}

The biomethanation of biomass derived syngas has not been in the spotlight yet and, as a result, there are scarce reports of continuous bioreactors performing this process [23]. One of the first attempts for 
methane production from a CO rich syngas mixture was demonstrated by Klasson et al. [30] who in contrast to the current study used a defined tri-culture of microbes (the photosynthetic bacterium R. rubrum performing the water-gas shift reaction and two hydrogenotrophic methanogens, $M$. formicicum and $M$. barkeri). The researchers compared two setups, a trickle bed bioreactor and a packed bubble column bioreactor and the maximum methane productivity rates achieved with each of the setups was 3.3 $\mathrm{mmol} / \mathrm{I}_{\text {bed }} / \mathrm{h}$ and $0.4 \mathrm{mmol} / \mathrm{I}_{\text {bed }} / \mathrm{h}$, respectively. It was reported that a $100 \%$ conversion of CO was possible up to an EBRT of $2.45 \mathrm{~h}$ and the maximum $\mathrm{CH}_{4}$ content in the exit of the trickle bed bioreactor was between $28 \%$ and $32 \%$. At a similar EBRT of $2.5 \mathrm{~h}$ in the present study, $93 \%$ of the introduced $\mathrm{H}_{2}$ and $88 \%$ of $\mathrm{CO}$ was converted resulting to a final $\mathrm{CH}_{4}$ content of $31 \%$. Nevertheless, in the present study there was no need for sterilization of the bioreactors due to the high diversity of the used enriched microbial consortia and no need for a light source to ignite photosynthetic growth. Based on their results, they recognized the advantage of the trickle bed reactor over the bubble column regarding the mass transfer rate of the sparingly soluble syngas compounds. Later, the same research group compared the performance of two trickle bed reactors with different volumes ( 1 I and $26 \mathrm{I}$ ) embodied with the aforementioned triculture and the same syngas mixture as a scale-up scenario [29]. Nonetheless, the high-volume reactor reached to a maximum $\mathrm{CH}_{4}$ productivity rate of $0.45 \mathrm{mmol} / \mathrm{l}_{\text {bed }} / \mathrm{h}$ at an EBRT of $8.7 \mathrm{~h}$, which was 6 times lower compared to the one reported for the low-volume reactor. The difference was attributed to the influence of the channeling phenomena since it was observed that the radial liquid distribution was more limited in the large reactor due to the selection of packing material with a 2 times bigger nominal diameter compared to the small reactor. This phenomenon is not expected to occur if a smaller size of packing material is selected so as to form narrower trickle paths in the bed and if the liquid is sprinkled in the bed through a nozzle in order to expand its distribution across the top surface of the column.

Westman et al. [37] demonstrated an alternative approach in order to overcome the bottlenecks of masstransfer limitation and low cell retention during syngas fermentation. The researchers encased anaerobic mixed microbial consortia from sewage sludge in porous hydrophilic polyvinylidene fluoride membranes 
with a shape of sachets and then placed them in a reverse flow reactor where syngas with a composition of

$255 \% \mathrm{CO}, 20 \% \mathrm{H}_{2}$ and $10 \% \mathrm{CO}_{2}$ was introduced from the bottom of the vessel. The maximum $\mathrm{CH}_{4}$ productivity achieved was $0.35 \mathrm{mmol} / \mathrm{I}_{\text {reactor }} / \mathrm{h}$ with a $95 \% \mathrm{H}_{2}$ and an $88 \% \mathrm{CO}$ conversion efficiency. They also compared their results with an identical setup where the cells were not encased in the sachets calculating the maximum methane productivity at $0.2 \mathrm{mmol} / \mathrm{I}_{\text {reactor }} / \mathrm{h}$, an observation that showed the advantageous performance of the biofilm based system that was able to tolerate higher syngas inflow rates. Compared to the present study a 10 -fold lower maximum $\mathrm{CH}_{4}$ productivity was achieved which can be attributed to the high content of $\mathrm{CO}$ in the inlet and a potential lower mass transfer rate of the selected bioreactor configuration. On a different perspective Guiot et al. [19] assessed the potential of a 30 I gas lift reactor inoculated with granular sludge to convert a gas stream containing only $\mathrm{CO}$ as a carbon and energy source in mesophilic conditions. When the gas recirculation rate was $29 \mathrm{l} / \mathrm{I}_{\text {reactor }} / \mathrm{d}$ and the $\mathrm{CO}$ retention time $8.6 \mathrm{~h}$, the $\mathrm{CH}_{4}$ productivity reached its maximum value of $0.126 \mathrm{mmol} / \mathrm{g}_{\text {vss }} / \mathrm{h}$ with a $67 \% \mathrm{CO}$ conversion efficiency and a $95 \%$ yield to $\mathrm{CH}_{4}$. The researchers argued that the low mass transfer of $\mathrm{CO}$ to the media was the reason that higher CO conversion efficiencies were not reached. In the present study, the conversion efficiency of CO reached a value as high as $93 \%$ at an EBRT of $3.25 \mathrm{~h}$. On the other hand Luo et al. [52] combined $\mathrm{CO}$ fermentation to $\mathrm{CH}_{4}$ with anaerobic digestion in a hollow fiber membrane bioreactor so as to assess the versatility of the formed biofilm to elevated pressures of $\mathrm{CO}$. The results showed that the microbial communities were able to tolerate the inhibitory effects of $\mathrm{CO}$ even at a pressure of $1.58 \mathrm{~atm}$ in the fibers and fully consumed it when the gas retention time was set at $4.8 \mathrm{~h}$. Besides syngas biomethanation, trickle bed bioreactors have been tested for similar biological processes such as $\mathrm{H}_{2} / \mathrm{CO}_{2}$ methanation and biogas upgrade. Compared to the inlet gas composition tested in this study, the biomethanation of $\mathrm{H}_{2} / \mathrm{CO}_{2}$ is occurring in a less adverse environment because of the absence of CO from the gas phase. Burkhardt et al. [32] deployed a 26.8 I counter-current flow trickle bed reactor inoculated with digested sewage sludge for the conversion of $80 \% \mathrm{H}_{2}$ and $20 \% \mathrm{CO}_{2}$. The maximum specific 
1 and a liquid recirculation rate of $10.7 \mathrm{l} / \mathrm{I}_{\text {bed }} / \mathrm{d}$. Based on these experiments the same research group

Table 6. Syngas biomethanation technologies reported in literature at their optimal conditions

\begin{tabular}{|c|c|c|c|c|c|c|c|}
\hline $\begin{array}{c}\text { Reactor } \\
\text { Type }\end{array}$ & $\begin{array}{c}\text { Volume } \\
(\mathbf{m l})\end{array}$ & $\begin{array}{c}\text { Temperature } \\
\left({ }^{\circ} \mathbf{C}\right)\end{array}$ & Inoculum & $\begin{array}{c}\text { Molar } \\
\text { Syngas } \\
\text { Composition }\end{array}$ & $\begin{array}{c}\mathbf{C H}_{4} \\
\text { Productivity } \\
\left(\mathbf{m m o l} / \mathbf{I}_{\text {bed }} / \mathbf{h}\right)\end{array}$ & $\begin{array}{c}\text { Gas } \\
\text { Retention } \\
\text { time (h) }\end{array}$ & Reference \\
\hline $\begin{array}{c}\text { Packed } \\
\text { bubble } \\
\text { column }\end{array}$ & 3260 & 34 & $\begin{array}{c}\text { Triculture } \\
\text { (R. rubrum, } \\
\text { M. } \\
\text { formicicum, }\end{array}$ & $\begin{array}{c}15 \% \mathrm{Ar}, \\
9.6 \% \mathrm{CO}, \\
55 \% \mathrm{CO},\end{array}$ & $\mathbf{0 . 4}$ & 7.24 & {$[30]$} \\
\hline
\end{tabular}
designed a continuous process with a scaled-up version of the reactor at $61 \mathrm{I}$ bed volume and the substrate was a gas mixture of $79 \% \mathrm{H}_{2}$ and $21 \% \mathrm{CO}_{2}$ [33]. At an EBRT of $3.16 \mathrm{~h}$ and a liquid recirculation rate of 3.1 $\mathrm{I} / \mathrm{l}_{\text {bed }} / \mathrm{d}$ the $\mathrm{CH}_{4}$ productivity was $2.78 \mathrm{mmol} / \mathrm{l}_{\text {bed }} / \mathrm{h}$ and $98 \% \mathrm{CH}_{4}$ concentration in the outflow. Finally, with the same bioreactor configuration in a lower scale (5.8 I) Rachbauer et al. [31] managed to fully convert 4:1 $\mathrm{H}_{2} / \mathrm{CO}_{2}$ to $\mathrm{CH}_{4}$ with a productivity of $3.4 \mathrm{mmol} / \mathrm{I}_{\text {bed }} / \mathrm{h}$ at an EBRT of $2.3 \mathrm{~h}$ and a liquid recirculation rate of 62 $\mathrm{I} / \mathrm{I}_{\text {bed }} / \mathrm{d}$. Compared to the present work similar maximum methane productivities were achieved in the aforementioned studies. The high concentration of $\mathrm{CH}_{4}$ in the outflow is a result of the perfect stoichiometric ratio of $\mathrm{H}_{2} / \mathrm{CO}_{2}$ in the inflow whereas in the present study the composition of syngas in the inflow is far from the ideal stoichiometry which would demand an additional supply of pure $\mathrm{H}_{2}$ with an inflow of 1.15 times the inflow rate of syngas.

A comparison between the efficiencies achieved during the present study with those from similar configurations already reported in the literature (Table 6) clearly shows that the used setup (reactor and microbial culture) is among the most efficient. It is anticipated that further optimization (composition of the mineral medium, choice of packing material and manner of gas and liquid injection in the reactor) can result in even higher methane productivities. In systems like those studied in this work, the size can play a significant role affecting their efficiency (see section 3.2.2 about wall effect and liquid introduction).

Therefore, it is expected that scaling up of the setup should be done with cautiousness taking into account all the challenges presented so far in the literature. 


\begin{tabular}{|c|c|c|c|c|c|c|c|}
\hline & & & M. barkeri) & $20.4 \% \mathrm{H}_{2}$ & & & \\
\hline $\begin{array}{l}\text { Trickle bed } \\
\text { reactor }\end{array}$ & 736 & 37 & $\begin{array}{c}\text { Triculture } \\
\text { (R. rubrum, } \\
M . \\
\text { formicicum, } \\
\text { M. barkeri) }\end{array}$ & $\begin{array}{c}14.8 \% \mathrm{Ar} \\
9.9 \% \mathrm{CO}_{2^{\prime}} \\
55.6 \% \mathrm{CO} \\
20.4 \% \mathrm{H}_{2}\end{array}$ & 3.3 & 2.45 & [30] \\
\hline $\begin{array}{l}\text { Trickle bed } \\
\text { reactor }\end{array}$ & 26052 & 37 & $\begin{array}{c}\text { Triculture } \\
\text { (R. rubrum, } \\
M . \\
\text { formicicum, } \\
\text { M. barkeri) }\end{array}$ & $\begin{array}{c}14.74 \% \mathrm{Ar} \\
9.72 \% \mathrm{CO}_{2^{\prime}} \\
54.42 \% \mathrm{CO} \\
21.11 \% \mathrm{H}_{2}\end{array}$ & 0.45 & 8.70 & [29] \\
\hline $\begin{array}{l}\text { Trickle bed } \\
\text { reactor }\end{array}$ & 1051 & 37 & $\begin{array}{c}\text { Triculture } \\
\text { (R. rubrum, } \\
\text { M. } \\
\text { formicicum, } \\
\text { M. barkeri) }\end{array}$ & $\begin{array}{c}14.82 \% \mathrm{Ar} \\
9.67 \% \mathrm{CO}_{2^{\prime}} \\
55.62 \% \mathrm{CO} \\
19.68 \% \mathrm{H}_{2}\end{array}$ & 2.8 & 2.10 & [29] \\
\hline $\begin{array}{c}\text { Reverse } \\
\text { membrane } \\
\text { bioreactor }\end{array}$ & 600 & 55 & $\begin{array}{l}\text { Anaerobic } \\
\text { culture } \\
\text { from } \\
\text { municipal } \\
\text { solid sludge } \\
\text { digester } \\
\end{array}$ & $\begin{array}{c}55 \% \mathrm{CO}, \\
20 \% \mathrm{H}_{2^{\prime}}, 10 \% \\
\mathrm{CO}_{2}\end{array}$ & 0.35 & $\begin{array}{c}\text { Not } \\
\text { mentioned }\end{array}$ & [37] \\
\hline $\begin{array}{l}\text { Trickle bed } \\
\text { reactor }\end{array}$ & 61000 & 37 & $\begin{array}{c}\text { Anaerobic } \\
\text { sludge from } \\
\text { sewage } \\
\text { plant }\end{array}$ & $\begin{array}{c}79 \% \mathrm{H}_{2}, 21 \% \\
\mathrm{CO}_{2}\end{array}$ & 2.78 & 3.2 & [32] \\
\hline $\begin{array}{l}\text { Trickle bed } \\
\text { reactor }\end{array}$ & 5800 & 37 & $\begin{array}{c}\text { Anaerobic } \\
\text { culture } \\
\text { from a } \\
\text { digester }\end{array}$ & $\begin{array}{c}80 \% \mathrm{H}_{2}, 20 \% \\
\mathrm{CO}_{2}\end{array}$ & 3.40 & 2.3 & [31] \\
\hline $\begin{array}{l}\text { Trickle bed } \\
\text { reactor }\end{array}$ & 180 & 37 & $\begin{array}{l}\text { Enriched } \\
\text { anaerobic } \\
\text { consortia }\end{array}$ & $\begin{array}{c}45 \% \mathrm{H}_{2}, 25 \% \\
\mathrm{CO}_{2}, 20 \% \\
\mathrm{CO}, 10 \% \mathrm{CH}_{4}\end{array}$ & 2.03 & 2.31 & $\begin{array}{l}\text { This study } \\
\text { (maximum } \\
\text { conversion) }\end{array}$ \\
\hline $\begin{array}{l}\text { Trickle bed } \\
\text { reactor }\end{array}$ & 180 & 37 & $\begin{array}{l}\text { Enriched } \\
\text { anaerobic } \\
\text { consortia }\end{array}$ & $\begin{array}{c}45 \% \mathrm{H}_{2}, 25 \% \\
\mathrm{CO}_{2}, 20 \% \\
\mathrm{CO}, 10 \% \mathrm{CH}_{4}\end{array}$ & 3.34 & 1.46 & $\begin{array}{l}\text { This study } \\
\text { (maximum } \\
\text { productivity) }\end{array}$ \\
\hline
\end{tabular}

\section{4. Conclusions}

3 The current study assessed the potential of enriched mixed microbial consortia derived from anaerobic

4 digesters to form rigid biofilms within two trickle bed bioreactors running in continuous mode for 297 days

5 and efficiently convert syngas to $\mathrm{CH}_{4}$. Moreover, the provided data highlight the key bottlenecks of the

6 process such as $\mathrm{pH}$ drop from the accumulation of acids and channeling phenomena in the bed.

7 Maintaining a steady $\mathrm{pH}$ (by $\mathrm{pH}$ control in case of full scale) in the reactors and guaranteeing a homogenous 
1 biofilm growth across the bed was vital for the improvement of the process. The results showed that $\mathrm{CH}_{4}$ productivity rates of $2 \mathrm{mmol} / \mathrm{l}_{\text {bed }} / \mathrm{h}$ can be achieved with a $93 \% \mathrm{H}_{2}$ and $90 \% \mathrm{CO}$ conversion efficiency and an $\mathrm{e}^{-}$yield of $78 \%$ at an EBRT of 2.31 hours, an HRT of 5.5 days and a liquid recirculation rate of $1600 \mathrm{l} / \mathrm{l}_{\text {bed }} / \mathrm{d}$. Higher $\mathrm{CH}_{4}$ productivities were also possible at a cost of the conversion efficiency of the substrate with the maximum value being $3.34 \mathrm{mmol} / \mathrm{l}_{\mathrm{bed}} / \mathrm{h}$ on the second reactor. It was also demonstrated that, despite the tremendous microbial diversity in these communities and the very long term parallel operation under the same operational parameters, the two reactors presented great reproducibility deviating rarely from one

8 another.

Overall, this work sheds more light on the sparsely researched topic of syngas biomethanation and addresses a new concept that enables the on-site conversion of biomass derived syngas to storable energy in the form of $\mathrm{CH}_{4}$. The acquired data constitute a strong basis for the further optimization of the process and they could be used as a background for the scaling-up of the set-up.

\section{References}

1. World Population Prospects 2017., United Nations, Department of Economic and Social Affairs, Population Division (2017). [Online]. Available:

2. International Energy Outlook 2017., U.S. Energy Information Administration, 2017. [Online]. Available: https://www.eia.gov/outlooks/ieo/pdf/0484(2017).pdf. [Accessed: 09-Dec-2017].

3. Nehring, R.: Traversing the mountaintop: world fossil fuel production to 2050. Philos Trans R Soc B Biol Sci, 364, 3067 LP-3079 (2009).

4. Hansen, J., Kharecha, P., and Sato, M.: Climate forcing growth rates: doubling down on our Faustian bargain. Environ Res Lett, 8, 011006 (2013). 
appraisal of second generation biofuels. Energy Policy, 63, 114-122 (2013).

6. Phillips, J. R., Huhnke, R. L., and Atiyeh, H. K.: Syngas Fermentation: A Microbial Conversion Process of Gaseous Substrates to Various Products. Fermentation, 3, 28 (2017).

7. Verma, D., Singla, A., Lal, B., and Sarma, P. M.: Conversion of Biomass-Generated Syngas into NextGeneration Liquid Transport Fuels through Microbial Intervention: Potential and Current Status. Curr Sci, 110, 329 (2016).

8. Liew, F., Martin, M. E., Tappel, R. C., Heijstra, B. D., Mihalcea, C., and Köpke, M.: Gas FermentationA Flexible Platform for Commercial Scale Production of Low-Carbon-Fuels and Chemicals from Waste and Renewable Feedstocks. Front Microbiol, 7, 694 (2016).

9. Mohammadi, M., Najafpour, G. D., Younesi, H., Lahijani, P., Uzir, M. H., and Mohamed, A. R.: Bioconversion of synthesis gas to second generation biofuels: A review. Renew Sustain Energy Rev, $15,4255-4273$ (2011).

10. Wainaina, S., Horváth, I. S., and Taherzadeh, M. J.: Biochemicals from food waste and recalcitrant biomass via syngas fermentation: A review. Bioresour Technol, 248, 113-121 (2018).

11. Dürre, P. and Eikmanns, B. J.: C1-carbon sources for chemical and fuel production by microbial gas fermentation. Curr Opin Biotechnol, 35, 63-72 (2015).

12. Molitor, B. et al.: Carbon recovery by fermentation of CO-rich off gases - Turning steel mills into biorefineries. Bioresour Technol, 215, 386-396 (2016).

13. Yang, L., Ge, X., Wan, C., Yu, F., and Li, Y.: Progress and perspectives in converting biogas to transportation fuels. Renew Sustain Energy Rev, 40, 1133-1152 (2014).

14. Henstra, A. M., Sipma, J., Rinzema, A., and Stams, A. J. M.: Microbiology of synthesis gas fermentation for biofuel production. Curr Opin Biotechnol, 18, 200-206 (2007). 
1 15. Grimalt-Alemany, A., Skiadas, I. V, and Gavala, H. N.: Syngas biomethanation: state-of-the-art review and perspectives. Biofuels, Bioprod Biorefining, 12, 139-158 (2018).

16. Klasson, K. T., Ackerson, C. M. D., Clausen, E. C., and Gaddy, J. L.: Biological conversion of synthesis gas into fuels. Int J Hydrogen Energy, 17, 281-288 (1992).

17. Dash, S., Ng, C. Y., and Maranas, C. D.: Metabolic modeling of clostridia: current developments and applications. FEMS Microbiol Lett, 363, fnw004 (2016).

18. Zabranska, J. and Pokorna, D.: Bioconversion of carbon dioxide to methane using hydrogen and hydrogenotrophic methanogens. Biotechnol Adv, 36, 707-720 (2018).

19. Guiot, S. R., Cimpoia, R., and Carayon, G. G.: Potential of wastewater-treating anaerobic granules for biomethanation of synthesis gas. Environ Sci Technol, 45, 2006-2012 (2011).

20. Alves, J. I., Stams, A. J. M., Plugge, C. M., Madalena Alves, M., and Sousa, D. Z.: Enrichment of

21. Demirel, B. and Scherer, P.: The roles of acetotrophic and hydrogenotrophic methanogens during

22. Munasinghe, P. C. and Khanal, S. K.: Syngas fermentation to biofuel: Evaluation of carbon monoxide

23. Asimakopoulos, K., Gavala, H. N., and Skiadas, I. V.: Reactor systems for syngas fermentation processes: A review. Chem Eng J, 348, 732-744 (2018). 
of mass transfer coefficients between trickle-bed, hollow fiber membrane and stirred tank reactors. Bioresour Technol, 133, 340-346 (2013).

25. Dupnock, T. L. and Deshusses, M. A.: High-Performance Biogas Upgrading Using a Biotrickling Filter and Hydrogenotrophic Methanogens. Appl Biochem Biotechnol, 183, 488-502 (2017).

26. Koutinas, M., Peeva, L. G., and Livingston, A. G.: An attempt to compare the performance of bioscrubbers and biotrickling filters for degradation of ethyl acetate in gas streams. J Chem Technol Biotechnol, (2005).

27. Alopaeus, V., Hynynen, K., and Aittamaa, J.: A cellular automata model for liquid distribution in trickle bed reactors. Chem Eng Sci, (2006).

28. Satterfield, C. N.: Trickle-bed reactors. AIChE J, 21, 209-228 (1975).

29. Kimmel, D. E., Klasson, K. T., Clausen, E. C., and Gaddy, J. L.: Performance of trickle-bed bioreactors for converting synthesis gas to methane. Appl Biochem Biotechnol, 28-29, 457-469 (1991).

30. Klasson, K. T., Cowger, J. P., Ko, C. W., Vega, J. L., Clausen, E. C., and Gaddy, J. L.: Methane Production from Synthesis Gas Using a Mixed Culture of R . rubrum , M . barkeri , and M . formicicum. Appl Biochem Biotechnol, 24, 317-328 (1990).

31. Rachbauer, L., Voitl, G., Bochmann, G., and Fuchs, W.: Biological biogas upgrading capacity of a hydrogenotrophic community in a trickle-bed reactor. Appl Energy, 180, 483-490 (2016).

32. Burkhardt, M. and Busch, G.: Methanation of hydrogen and carbon dioxide. Appl Energy, 111, 74-79 (2013).

33. Burkhardt, M., Koschack, T., and Busch, G.: Biocatalytic methanation of hydrogen and carbon dioxide in an anaerobic three-phase system. Bioresour Technol, 178, 330-333 (2015). 
1 34. Strübing, D., Huber, B., Lebuhn, M., Drewes, J. E., and Koch, K.: High performance biological methanation in a thermophilic anaerobic trickle bed reactor. Bioresour Technol, 245, 1176-1183 (2017).

35. Strübing, D., Moeller, A. B., Mößnang, B., Lebuhn, M., Drewes, J. E., and Koch, K.: Anaerobic thermophilic trickle bed reactor as a promising technology for flexible and demand-oriented $\mathrm{H} 2 / \mathrm{CO} 2$ biomethanation. Appl Energy, 232, 543-554 (2018).

36. Youngsukkasem, S., Chandolias, K., and Taherzadeh, M. J.: Rapid bio-methanation of syngas in a

37. Westman, S., Chandolias, K., and Taherzadeh, M.: Syngas Biomethanation in a Semi-Continuous

38. Arantes, A. L., Alves, J. I., Stams, A. J. M., Alves, M. M., and Sousa, D. Z.: Enrichment of syngasconverting communities from a multi-orifice baffled bioreactor. Microb Biotechnol, 11, 639-646 Reverse Membrane Bioreactor (RMBR). Fermentation, 2, 8 (2016). (2018).

39. Grimalt-Alemany, A., Łężyk, M., Kennes-Veiga, D. M., Skiadas, I. V., and Gavala, H. N.: Enrichment of Mesophilic and Thermophilic Mixed Microbial Consortia for Syngas Biomethanation: The Role of Kinetic and Thermodynamic Competition. Waste and Biomass Valorization, (2019).

40. WOLIN, E. A., WOLIN, M. J., and WOLFE, R. S.: FORMATION OF METHANE BY BACTERIAL EXTRACTS. J Biol Chem, (1963).

41. Grimalt-Alemany, A., Łęzyk, M., Lange, L., Skiadas, I. V., and Gavala, H. N.: Enrichment of syngasconverting mixed microbial consortia for ethanol production and thermodynamics-based design of enrichment strategies. Biotechnol Biofuels, (2018). 
42. Sancho Navarro, S., Cimpoia, R., Bruant, G., and Guiot, S. R.: Biomethanation of Syngas Using Anaerobic Sludge: Shift in the Catabolic Routes with the CO Partial Pressure Increase. Front Microbiol, 7, 1188 (2016).

43. Oelgeschläger, E. and Rother, M.: Carbon monoxide-dependent energy metabolism in anaerobic bacteria and archaea., Archives of Microbiology. 2008.

44. Esquivel-Elizondo, S., Miceli, J., Torres, C. I., and Krajmalnik-Brown, R.: Impact of carbon monoxide partial pressures on methanogenesis and medium chain fatty acids production during ethanol fermentation. Biotechnol Bioeng, 115, 341-350 (2018).

45. Rachbauer, L., Beyer, R., Bochmann, G., and Fuchs, W.: Characteristics of adapted hydrogenotrophic community during biomethanation. Sci Total Environ, 595, 912-919 (2017).

46. Bu, F., Dong, N., Kumar Khanal, S., Xie, L., and Zhou, Q.: Effects of $\mathrm{CO}$ on hydrogenotrophic methanogenesis under thermophilic and extreme-thermophilic conditions: Microbial community and biomethanation pathways. Bioresour Technol, 266, 364-373 (2018).

47. Dong, N., Bu, F., Zhou, Q., Khanal, S. K., and Xie, L.: Performance and microbial community of hydrogenotrophic methanogenesis under thermophilic and extreme-thermophilic conditions. Bioresour Technol, 266, 454-462 (2018).

48. Kougias, P. G., Treu, L., Benavente, D. P., Boe, K., Campanaro, S., and Angelidaki, I.: Ex-situ biogas upgrading and enhancement in different reactor systems. Bioresour Technol, 225, 429-437 (2017).

49. Mederos, F. S., Ancheyta, J., and Chen, J.: Review on criteria to ensure ideal behaviors in trickle-bed reactors., Applied Catalysis A: General. 2009.

50. De Vela, R. J. L. and Gostomski, P. A.: Minimising biomass accumulation in biotrickling filters. Rev Environ Sci Bio/Technology, 17, 417-430 (2018). 
1 51. Wu, H., Yan, H., Quan, Y., Zhao, H., Jiang, N., and Yin, C.: Recent progress and perspectives in biotrickling filters for VOCs and odorous gases treatment. J Environ Manage, 222, 409-419 (2018).

3 52. Luo, G., Wang, W., and Angelidaki, I.: Anaerobic Digestion for Simultaneous Sewage Sludge Treatment and CO Biomethanation: Process Performance and Microbial Ecology. Environ Sci Technol, 47, 130904143045005 (2013). 